NBER WORKING PAPER SERIES

\title{
WHAT DO WE KNOW ABOUT SHORT AND LONG TERM EFFECTS OF EARLY LIFE EXPOSURE TO POLLUTION?
}

\author{
Janet Currie \\ Joshua S. Graff Zivin \\ Jamie Mullins \\ Matthew J. Neidell \\ Working Paper 19571 \\ http://www.nber.org/papers/w19571 \\ NATIONAL BUREAU OF ECONOMIC RESEARCH \\ 1050 Massachusetts Avenue \\ Cambridge, MA 02138 \\ October 2013
}

Currie thanks the John D. and Catherine T. MacArthur foundation for financial support. Graff Zivin and Neidell are grateful for funding from the National Institute of Environmental Health Sciences (1R21ES019670-01). The views expressed herein are those of the authors and do not necessarily reflect the views of the National Bureau of Economic Research.

At least one co-author has disclosed a financial relationship of potential relevance for this research. Further information is available online at http://www.nber.org/papers/w19571.ack

NBER working papers are circulated for discussion and comment purposes. They have not been peerreviewed or been subject to the review by the NBER Board of Directors that accompanies official NBER publications.

(C) 2013 by Janet Currie, Joshua S. Graff Zivin, Jamie Mullins, and Matthew J. Neidell. All rights reserved. Short sections of text, not to exceed two paragraphs, may be quoted without explicit permission provided that full credit, including $(\mathcal{C}$ notice, is given to the source. 
What Do We Know About Short and Long Term Effects of Early Life Exposure to Pollution? Janet Currie, Joshua S. Graff Zivin, Jamie Mullins, and Matthew J. Neidell

NBER Working Paper No. 19571

October 2013

JEL No. I1,I12,J24,Q5,Q53

\begin{abstract}
$\underline{\text { ABSTRACT }}$
Pollution exposure early in life is detrimental to near-term health and an increasing body of evidence suggests that early childhood health influences health and human capital outcomes later in life. This paper reviews the economic research that brings these two literatures together. We begin with a conceptual model that highlights the core relationships across the lifecycle. We then review the literature concerned with such estimates, focusing particularly on identification strategies to mitigate concerns regarding endogenous exposure. The nascent empirical literature provides both direct and indirect evidence that early childhood exposure to pollution significantly impacts later life outcomes. We discuss the potential policy implications of these long-lasting effects, and conclude with a number of promising avenues for future research.

Janet Currie

Princeton University

316 Wallace Hall

Princeton, NJ 08544

and NBER

jcurrie@princeton.edu

Joshua S. Graff Zivin

University of California, San Diego

9500 Gilman Drive, MC 0519

La Jolla, CA 92093-0519

and NBER

jgraffzivin@ucsd.edu

Jamie Mullins

University of California, San Diego

9500 Gilman Drive

La Jolla, CA 92093

jmullins@ucsd.edu

Matthew J. Neidell

Department of Health Policy and Management

Columbia University

722 W 168th Street, 6th Floor

New York, NY 10032

and NBER

mn2191@columbia.edu
\end{abstract}




\section{Introduction}

The protection of human health is a principal motivation for environmental regulation around the world. Children are particularly vulnerable to environmental exposures because their immune and other bodily systems are still developing and they often engage in behaviors that increase their exposure to toxic chemicals and organisms, e.g. they spend more time outside than adults (U.S. EPA 2013; Bateson \& Schwartz 2007; Makri et al. 2004; Schwartz 2004). Rapid cell division and an intense phase of epigenetic programming make the prenatal and immediate postnatal period an especially sensitive one (Baccarelli \& Bollati 2009; Gluckman et al. 2008; Holt 1998). As such, the protection of children has become a driving force behind many environmental regulations. ${ }^{1}$

The impacts of early life pollution exposure are of interest for non-health reasons as well. Early life health affects long-term outcomes including human capital accumulation, labor force participation and earnings (see Almond \& Currie 2011 for a review of this literature). Thus, the marginal returns to regulations that protect children may be both large and rather diffuse in that they affect many outcomes. ${ }^{2}$

In addition to broadening the focus beyond health, economists have made two important methodological contributions to the study of pollution impacts on children. First, economists have developed a conceptual framework for considering the effects of pollution within the larger frame of health production and investments. The framework implies, for example, that a lifetime of investments may strengthen or attenuate the pure biologic insults experienced early in life. It also highlights that optimizing behavior, through residential sorting, can lead to non-random assignment of pollution. For example, as discussed further

\footnotetext{
${ }^{1}$ In the U.S., for example, Executive Order 13045 directs the EPA and other federal agencies to "ensure that its policies, programs, activities, and standards address disproportionate risks to children that result from environmental health risks or safety risks” (Clinton 1997).

${ }^{2}$ Large returns to early life interventions have been found in a number of settings outside of environmental health (Currie 2001; Heckman 2000, Schweinhart et al. 1993; 2005).
} 
below, individuals with higher incomes are both less likely to raise their families in areas of poor environmental quality, and more likely to make greater investments in their children’s health. Failing to account for the correlation of higher health investments with living in an area with better environmental quality will bias estimates of the effects of pollution.

Similarly, an optimizing framework leads to the consideration of avoidance behavior. Since the consequences of toxic exposures are costly, particularly to children, parents may engage in activities to prevent them. Avoidance behavior can muddy the measurement of biologic effects in epidemiologic research. Ignoring avoidance behavior can also lead to significant underestimation of the social welfare costs of pollution since a narrow focus on the costs of morbidity and mortality will exclude the costs of avoidance activities (Courant \& Porter 1981; Harrington \& Portney 1987; Bartik 1988).

A second, and related contribution in light of concerns regarding endogenous exposure to pollution, is the use of quasi-experimental techniques to develop causal estimates of the effects of early-life pollution. The shorter possible exposure period and more limited geographic mobility of children make it easier to use quasi-experimental methods to determine the effects of pollution on children relative to adults. Such causal inference has enabled the detection of effects at markedly low levels of pollution.

A third contribution of economists involves the explicit consideration of welfare and willingness-to-pay (WTP) for reductions in pollution. As discussed below, the data requirements for a complete WTP calculation are seldom met, but partial calculations may still be useful for policy.

This paper reviews the recent economic literature on the effects of early life exposure to pollution. We focus primarily on air pollution since it has received the most attention in the literature, largely due to greater data availability. The remainder of the paper is organized as follows. The next section describes the contribution of economics to our understanding of 
the impacts of early life pollution exposure. We begin with a conceptual model, followed by a discussion of identification and welfare. Section III provides a structured review of the literature that organizes papers into common themes. Section IV offers some concluding remarks and suggestions for future research.

\section{What Do Economists Bring to the Table?}

\section{Conceptual Model}

In this section, we develop a simple three-period model that builds upon earlier work on human capital accumulation and investments (Grossman 1972; Cunha \& Heckman 2007; Almond \& Currie 2011) to highlight the salient features that link pollution and birth outcomes to health and human capital later in life.

Our framework divides life into three distinct stages: early childhood, late childhood, and adulthood. To fix ideas, one can view early childhood as beginning in utero and ending at age 5. Late childhood would comprise the school years, and adulthood can be viewed as the post-schooling period when people have typically entered the labor force. For simplicity, we model the human capital production function of a representative individual and abstract from the endogeneity of pollution exposure, though we return to this problem in the next section (Neidell 2009; Graff Zivin et al. 2011; Currie et al. 2011). ${ }^{3}$

Assume that early childhood human capital $\mathrm{H}_{\mathrm{E}}$ is dependent on early childhood pollution exposure $\mathrm{P}_{\mathrm{E}}$ and time-invariant family characteristics $\mathrm{X}$, such as genetics.

$H_{E}=f_{E}\left(P_{E}, X\right)$

Late childhood human capital $\mathrm{H}_{\mathrm{L}}$ depends on late childhood pollution exposure $\mathrm{P}_{\mathrm{L}}$ and the human capital accumulated during early childhood. Importantly, families can make

\footnotetext{
${ }^{3}$ Individuals may differ in their susceptibility to pollution for a variety of reasons apart from the explicit differences by stage of life that we attend to here. This heterogeneity will affect the gradient between childhood and adult outcomes, but the basic insights from the model remain the same.
} 
investments $I_{L}$ in their child that influence the legacy of those early childhood outcomes. Those investments will depend upon realizations of human capital in the first stage of life.

$H_{L}=f_{L}\left(I_{L}\left(H_{E}\right), P_{L}\right)$

Finally, assume that adult outcomes $\mathrm{H}_{\mathrm{A}}$ depend on both early and late childhood human capital. Given our focus on children, we ignore adult exposure to pollution and investments in human capital, such that adults in our model should be viewed as 'fully formed.' Human capital in adulthood is broadly construed to reflect the fact that pollution can affect cognitive attainment and earnings as well as health (Graff Zivin \& Neidell 2013).

$H_{A}=f_{A}\left(H_{E}, H_{L}\right)$

Equations (1)-(3) imply that the impacts of early childhood pollution exposure on adult human capital will depend upon its short-run effects as well as the propagation of those effects through the rest of the life cycle. These pathways are easily shown by taking the total derivative of (3):

$\frac{d H_{A}}{d P_{E}}=\frac{\partial f_{A}}{\partial H_{E}} \frac{\partial H_{E}}{\partial P_{E}}+\frac{\partial f_{A}}{\partial H_{L}} \frac{\partial H_{L}}{\partial P_{E}}$

Note that $P_{E}$ (or $P_{L}$ ) may also have a direct, latent effect on $H_{A}$, which does not act through changes in $H_{E}$ or $H_{L}$. For the time being we ignore the partial derivatives of $H_{A}$ with respect to $P_{E}$ and $P_{L}$ though we return to the question of latent effects below.

Our model of human capital accumulation can be used to illustrate several points regarding childhood exposure to pollution. As discussed above, it is reasonable to assume that the early childhood period is one of greater sensitivity to pollution. The nine months in utero is a critical period for physiological development and an increasing body of evidence suggests that fetal programming can be adversely impacted by toxic exposures (Almond \& Currie 2011; Barker 1990; Bateson \& Schwartz 2007). All else equal, this suggests that an equal dose of pollution will have a bigger effect (in absolute value) in early childhood: 
$\left|\frac{\partial H_{E}}{\partial P_{E}}\right|>\left|\frac{\partial H_{L}}{\partial P_{L}}\right| \quad \forall P_{E}=P_{L}$

In addition to greater contemporaneous health effects, early life exposures can result in latent health impacts. In particular, pollution may have epigenetic effects - permanent alterations in gene expression - that can negatively impact intellectual growth and maturity later in life (Petronis 2010). Someone with latent epigenetic damage might initially appear to be in perfect health so that it might be possible to observe the following:

$\left|\frac{\partial H_{E}}{\partial P_{E}}\right|=0$ and $\left|\frac{\partial H_{A}}{\partial P_{E}}\right|>0$

The long potential latency period between exposure and the outcomes of interest also provides ample opportunity for effects to be amplified or dampened. Self-productivity and dynamic complementarities in health and learning, whereby capabilities beget capabilities in a multi-stage framework, suggest that early health shocks will be multiplied over the life cycle (Cunha \& Heckman 2007). The early manifestation of health and cognitive deficits could induce parental (dis)investments in early childhood that will also impact later life outcomes. Whether parents compensate for poor endowments at birth by increasing investments in those children or reinforce poor endowments by directing their efforts toward children with better prospects is an open empirical question in the literature (Behrman et al. 1994; Datar et al. 2010). If we expand the last term of equation (4) above, the role of these investments can be made more explicit:

$\frac{d H_{A}}{d P_{E}}=\frac{\partial f_{A}}{\partial H_{E}} \frac{\partial H_{E}}{\partial P_{E}}+\frac{\partial f_{A}}{\partial H_{L}}\left(\frac{\partial f_{L}}{\partial I_{L}} \frac{\partial I_{L}}{\partial H_{L}} \frac{\partial H_{L}}{\partial P_{E}}\right)$

Assuming that the effects of pollution exposure are detrimental, self-productivity and dynamic complementarities imply that $\frac{\partial H_{L}}{\partial P_{E}}$ is large and negative - early deficits compound over the life cycle such that the impacts later can be quite large. Compensatory investments correspond to the case where $\frac{\partial I_{L}}{\partial H_{L}}$ is negative, while reinforcing ones imply that this term is positive. 
The principal value of equation (7) is conceptual. Data limitations imply that all empirical investigations in this area will paint a partial picture of this total derivative. Nonetheless, the equation underscores the connections across a wide range of empirical literatures within economics, including the environmental, education, labor and health fields. This basic model also highlights the policy importance of the question addressed in this review. If the legacy effects of early pollution exposures are large, then even modest interventions to protect young children may have profound impacts on societal well-being and future economic growth. Of course, such benefits would have to be weighed against the costs of any regulatory efforts to protect children, and a proper welfare calculation should incorporate the costs borne by households seeking to avoid pollution and/or to compensate for its effects.

\section{An Emphasis on Identification}

While the conceptual model just described intentionally eschewed concerns about the endogeneity of pollution exposure, empirical economic studies on the effects of the environment on child health have not. Endogeneity can arise through two primary channels. The first is Tiebout sorting (Tiebout 1956), through which people "vote with their feet" by choosing residential locations based on area characteristics, such as pollution levels or attributes coincidentally correlated with pollution levels. A growing body of empirical evidence suggests that sorting based on environmental quality is indeed a major factor affecting residential location. For example, Banzhaf \& Walsh (2008) find that high income families tend to move away from highly polluted areas, while Currie (2011), Currie et al., (2011), and Currie \& Walker (2011) find that improving environmental quality in an area increases the share of pregnant women who are white and college-educated. As a result of this sorting, areas with higher levels of pollution may also have other unobserved 
characteristics correlated with health, suggesting that omitted variable bias is likely to confound estimates. ${ }^{4}$

The second source of endogeneity arises from avoidance behavior. If individuals take actions to protect their children's health when pollution is high, these actions will lead to nonrandom assignment of ex post pollution exposure. These kinds of actions require knowledge of pollution levels, either through experiential changes in health or, as may be more likely for younger children, through publicly provided information. The dissemination of pollution information to the public is mandated in many large cities, and is often accompanied by recommended strategies for pollution avoidance, such as staying indoors or shifting activities to times of the day when pollution is expected to be lower.

Since avoidance behavior is an ex post decision- it occurs in response to realized pollution levels -- its omission from analysis does not introduce a bias per se in estimates, but rather affects the interpretation of estimated relationships. Estimates that account for avoidance behaviour uncover the direct biological effect of pollution on health $\left(\partial H_{A} / \partial P_{E}\right)$. Estimates that do not account for avoidance measure a reduced form effect of pollution on health, which consists of the biological effect plus the degree to which avoidance behavior $\left(A_{B}\right)$ is successful in averting detrimental health effects $\left(d H_{A} / d P_{E}=\partial H_{A} / \partial P_{E}+\partial H_{A} / \partial A_{B}\right.$ $\left.\partial A_{B} / \partial P_{E}\right)$. Both estimates can be used to monetize the benefits from improvements in environmental quality, so the focus of estimation depends on the research question.

Economists have addressed endogeneity concerns with quasi-experimental techniques such as finding natural experiments that result in unexpected "shocks” to environmental quality. These shocks can be driven by government regulation (such as the Clean Air Acts in the United States), unexpected changes in industrial production (such as strikes and plant closings), or catastrophic events (such as temperature inversions or wildfires). Another

\footnotetext{
${ }^{4}$ We also note that pollution, rather than people, may "sort” whereby polluting industries locate in areas with lower land prices, which also tend to be areas with residents of lower socioeconomic status.
} 
approach consists of exploiting high frequency variability in pollution over short periods of time in conjunction with local area fixed effects, under the assumption that sorting in response to environmental changes occurs more slowly than health changes. A final approach consists of within family designs, such as sibling comparisons, which hold fixed many unobserved characteristics common to children from the same family.

While each approach has its advantages, there are important limitations that must be recognized. For example, although an unexpected productivity shock can affect air pollution, it may also directly affect health through job losses or the loss of health insurance (von Wachter \& Sullivan 2009). And the more time is allowed to elapse from the time of the shock, the greater the probability that residential sorting will complicate the picture. Natural experiments also do little to directly address ex post avoidance behaviour. Despite these limitations, we will show below that the weight of the evidence suggests that early life exposure to pollution has negative long term effects.

\section{Welfare Calculations to Guide Policy}

Environmental economics research often aims to develop measures of willingness-topay for reductions in pollution. Such estimates are necessary to inform environmental policy. While the theory underlying the computation of WTP is clear (Harrington \& Portney 1987; Cropper \& Freeman 1991), there are few studies that combine an emphasis on quasiexperimental identification strategies with WTP calculations. One likely explanation is the massive data requirements to compute a complete WTP - in principal, WTP must include measures of all outcomes affected, all types of avoidance behavior undertaken, and the disutility (such as pain and suffering) associated with any health effects. ${ }^{5}$ As a result, economists often compute partial cost-benefit analyses, noting that the computed benefits

\footnotetext{
${ }^{5}$ See Deschênes et al. (2012) for an example of one of the most comprehensive estimates of WTP.
} 
understate the complete WTP for a particular policy. It is also worth noting that, since economic studies are typically designed to test whether a null hypothesis can be rejected, the common practice is to employ conservative assumptions that bias estimated effects of the particular outcome of interest toward zero. ${ }^{6}$ Hence reported magnitudes often provide only a lower bound on the magnitude of the effect. In the end, a policy recommendation is only clear if even these understated benefits exceed costs.

\section{Literature Review}

Tables 1 to 4 summarize the existing quasi-experimental research in economics on the effects of pollution on children's well-being. Tables 1 through 3 focus on air pollution, which is often the most reliably recorded measure of environmental quality. Table 4 summarizes the much smaller literature on water pollution. A general feature of this literature is that, while impacts are often attributed to a single pollutant, emissions of many pollutants tend to be highly correlated and may come from the same sources. For example, an analysis of the effect of carbon monoxide exposure on birth weight may really be measuring the effect of automobile exhaust, which includes particulate matter, nitrogen oxides, and other chemicals in addition to carbon monoxide. Even analyses based on multipollutant models rarely have measures of all relevant emissions. If all pollutants are emitted from the same source, this may not matter from a policy perspective but it will certainly limit generalizability across settings.

\section{Long Term Effects of Air Pollution}

Table 1 shows that relatively few studies make a direct connection between childhood exposure to pollution and long-term outcomes such as educational attainment and earnings.

\footnotetext{
${ }^{6}$ An example is sibling fixed effects estimates which are known to be biased towards zero in the presence of random measurement error.
} 
The small number of studies is largely due to limitations in data availability: Data that allows the linkage of adult outcomes with childhood environmental quality is rare. In the absence of such data, some researchers have employed a cohort approach to exploit differences between cohorts of children born just before and after an environmental shock. This approach generally works best in the case of a large shock.

Almond et al. (2009) studied the fallout from the Chernobyl nuclear disaster using detailed Swedish administrative data. Although Sweden is more than 500 miles away from Chernobyl, weather conditions forced some of the plume of radioactive particles to pass over Sweden. Local variation in rainfall levels led to stark geographic variation in the levels of fallout throughout the country. By comparing cohorts in affected and unaffected areas, and cohorts in utero just prior to the disaster and during the disaster, they demonstrate that radiation exposure reduced overall grades by 2.5 percentage points and mathematics test scores by 6 percentage points despite the fact that the amounts of radiation involved were below thresholds widely considered, at the time, to be safe. They also found no immediate effects on health, as measured by birth outcomes and childhood hospitalizations, underscoring the latent nature of these effects. ${ }^{7}$

Black et al. (2013) conduct a similar analysis of the effect of radiation exposure in the $8^{\text {th }}$ to $16^{\text {th }}$ weeks of pregnancy due to fallout from nuclear tests. Using data from Norway, they first show that test frequency, proximity to the coast, and rainfall patterns influenced the deposition of fallout. They find that a one standard deviation increase in exposure decreased IQ scores by .025 of a standard deviation. Exposure also led to reductions in years of schooling and adult earnings.

Using a large dataset that follows Chilean children from birth, Bharadwaj et al. (2013) examine the relationship between air pollution exposure in each month of pregnancy and $4^{\text {th }}$

\footnotetext{
${ }^{7}$ It is notable that the radiation levels found in Sweden are quite comparable to those emitted by radon and used in medical radiation. However, policy levers for influencing exposure from such sources are quite different from typical environmental policy.
} 
and $8^{\text {th }}$ grade test scores. They find significant effects of exposure to carbon monoxide (and its correlates) and ozone in the $3^{\text {rd }}$ and $4^{\text {th }}$ months of pregnancy, a timing that is consistent with the results found in Black et al. (2013) and Almond et al. (2009).

Nilsson (2009) investigates the long-term impact of banning leaded gasoline in Sweden during the 1970s. In an innovative design, he used measures of lead from moss samples, to infer ambient lead levels in different areas of the country and is able to show a wide geographic dispersion of lead across space and over time. Linking the decline in ambient lead around the time of birth to later outcomes for the affected cohorts, his estimates imply that reducing lead levels from 10 to 5 micrograms per deciliter (the current regulatory standard in the U.S. is 15 ) increased high school graduation rates by $2.3 \%$ and earnings among young adults by 5.5\%. The effects were larger for children of lower socioeconomic status.

Sanders (2012) builds on the work of Chay \& Greenstone (2003b; discussed below) by asking whether cohorts affected by the reductions in U.S. pollution caused by the recession of the early 1980s scored better on high school tests. A drawback to his analysis is that he cannot identify where the mother resided when the children were born, so he is forced to assume that children were born in the place they attended high school. Despite this potential source of measurement error, he finds that a one standard deviation decrease in Total Suspended Particles around the time of birth increases high school test scores by 1.87 standard deviations.

Isen et al. (2013) are able to go further with a similar approach by using restricted access data on adult earnings that includes information on the actual county and date of birth of each worker. Their identification strategy follows Chay \& Greenstone (2003a) in using the pollution reductions due to the passage of the 1970 U.S. Clean Air Act Amendments as a source of variation in pollution levels. Counties that were out of compliance with the new 
CAA pollution thresholds were identified as non-compliant and were required to lower pollution, while counties with pollution levels just below the thresholds were not required to implement any changes. Comparing counties initially just below the threshold to those just above, they find that each $10 \mathrm{ug} / \mathrm{m}^{3}$ decrease in Total Suspended Particles during pregnancy and early childhood resulted in a 1\% increase in annual salaries. Of course, ambient levels of particulates have fallen greatly since the 1970s, so it is not clear that a similar decline in the U.S. today would have the same impact.

\section{Air Pollution and Infant Health}

Given the difficulty in making a direct connection between early life exposure to pollution and later outcomes, much of the literature focuses on the effects of pollution on fetal and infant health and then relies on the growing literature linking health at birth to longterm outcomes in order to make inferences about the likely long-term effects. The most commonly used measures of early childhood health are birth weight (especially low birth weight, defined as less than 2500 grams), prematurity (defined as gestation less than 37 weeks), and either infant mortality (death within the first year of life) or neonatal mortality (death within the first month of life). The literature focusing on the effects of pollution on infant health is summarized in Table 2. The studies in Table 2 are organized according to whether the country is a developed or a developing country, and whether the pollutant is a criterion air pollutant or another type of pollutant.

\section{i. Developed countries}

Chay \& Greenstone (2003a, b) conducted two landmark studies on the effects of air pollution. The first study (Chay \& Greenstone 2003a) pioneered the research design based on the Clean Air Acts discussed above and used in subsequent studies. Applying this design to county level data, they estimated that a one unit decline in particulates led to 5-8 fewer 
infant deaths per 100,000 live births. Sanders \& Stoecker (2011), using the same natural experiment, examine the effects of pollution on sex ratios at birth. Since male fetuses are thought to be more fragile than female fetuses, a decrease in the ratio of male live births to female live births is suggestive of an increase in fetal losses. Consistent with this hypothesis, they find that a reduction in pollution increases the fraction of male fetuses. The second Chay \& Greenstone study (2003b) looked at the recession of 1982, which lowered pollution in areas that experienced larger declines in manufacturing (i.e.- the research design followed by Sanders 2012). These pollution reductions led to significant decreases in infant mortality. ${ }^{8}$

The levels of particulates studied by Chay and Greenstone are much higher than those prevalent today; for example, U.S. $\mathrm{PM}_{10}$ (particulate matter of 10 microns or less) levels fell by nearly 50 percent from 1980-2000. Moreover, the Chay and Greenstone studies are only able to examine the effects of particulates since other pollutants were not yet widely measured. In a similar inquiry, Currie \& Neidell (2005) focus on a more recent time period when additional pollution measures are available. For identification they use high-frequency variation in pollution within zip codes over time. A disadvantage of this approach is that people living in persistently more polluted or higher variance areas may be systematically different from other people in ways that might correlate with their children's health. In order to control for these differences, Currie and Neidell include zip code fixed effects and zip code specific time trends and demonstrate that decreases in CO led to improvements in infant mortality.

In a related study, Currie et al. (2009b) used a large sample of infants born in New Jersey from 1989-2006 who were subjected to different levels of pollution in utero. They control for fixed elements of family background shared by siblings by including family fixed

\footnotetext{
${ }^{8}$ Arguably, Chay and Greenstone were inspired by a series of epidemiological studies investigating the health effects of the opening and closing of a steel mill in Utah in the 1980s (Pope 1989; Pope et al. 1992; Ransom and Pope 1995). Others have been inspired by these studies as well, for example Parker et al. (2008) returned to the same natural experiment and found that preterm births declined when the mill was closed but rebounded when it reopened.
} 
effects. They also focused on a sample of mothers who lived near pollution monitors in order to improve their assignment of pollution exposure. They found that babies exposed in utero to higher levels of carbon monoxide suffered reduced birth weight and gestation length relative to their siblings, even though ambient CO levels were generally lower than current Environmental Protection Agency (EPA) standards. Their estimates imply that on average, moving from a high to low CO area would have a larger effect on infant health than having a pregnant woman reduce her smoking from ten cigarettes a day to zero.

Since many papers find negative health effects of CO, and CO comes mostly from cars, Currie \& Walker (2011) exploited the introduction of electronic toll collection devices (E-ZPass) in New Jersey and Pennsylvania to directly examine the effect of automobile exhaust on infant health. Much of the pollution produced by automobiles occurs during idling and acceleration, so the introduction of E-ZPass greatly reduced auto emissions near toll plazas. For example, E-ZPass reduced CO by about $40 \%$ in the vicinity of toll plazas. Comparing mothers near toll plazas $(<2 \mathrm{~km})$ to those who lived along the same busy roadways but further away from toll plazas $(2-10 \mathrm{~km})$, they found that E-Zpass reduced the incidence of low birth weight and prematurity by about 10\%. In a related paper, Knittel et al. (2011) examined the effect of traffic congestion in California using data on traffic jams that temporarily increased pollution levels. They also found significant effects of even relatively low levels of pollution on infant mortality rates.

Recently, the number of studies conducted outside of the U.S. has grown considerably. Using a design similar to Currie \& Neidell (2005), Coneus \& Spiess (2010) found large effects of CO on infant health in Germany. Luchinger (2010), also focusing on Germany, used the mandating of $\mathrm{SO}_{2}$ scrubbers in power plants as a natural experiment. He found that reductions in $\mathrm{SO}_{2}$ led to significant decreases in the rate of infant mortality. Janke et al. (2009) examine the relationship between localized pollution levels in Great Britain 
between 1998 and 2005 and the deaths of children under $15 .^{9}$ They estimate that a reduction of $10 \mathrm{ug} / \mathrm{m} 3$ in $\mathrm{PM}_{10}$ is associated with 4 fewer deaths per 100,000.

\section{ii. Developing countries}

The impacts of pollution in developing countries are of independent interest since pollution levels are generally higher and infant health is often much worse than in more developed countries. Thus, the same health insults may have larger effects, and the data may also be used to test for potential non-linear effects of pollution. However, while data on pollution and health are often reliably recorded in more developed nations, such data may be more difficult to obtain in less developed countries. Jayachandran (2009) overcomes this obstacle by using satellite aerosol measures to track smoke from fires in Indonesia in 1997, and using data on "missing children" to infer infant mortality. She finds a reduction in cohort size for those exposed to the fires' smoke during the third trimester of pregnancy, and calculates that the fires resulted in a $20 \%$ increase in deaths among fetuses and children less than 3 years of age.

Foster et al. (2009) also use satellite measurements to approximate pollution levels throughout Mexico. Using participation in a voluntary pollution reduction program as an instrumental variable, they show that reductions in pollution improve infant mortality from respiratory causes. Also focused on Mexico, Arceo-Gomez et al. (2012) use thermal inversions, which trap pollution, as an instrumental variable, and find that CO has stronger per unit effects on infant mortality than in the U.S.

Cesur et al. (2013) examined the switch from coal to natural gas in Turkey and found that a one percentage point increase in subscriptions to natural gas was associated with a four percent decline in infant mortality. A notable feature of this study is that instead of focusing on the effect of a pollutant per se, they focus on a change in fuel delivery, which is perhaps

\footnotetext{
${ }^{9}$ We have included this in the infant health table since the vast majority of such deaths are for infants under 1 year of age.
} 
more relevant from a policy perspective. Greenstone \& Hanna (2011) use air pollution data from 140 Indian cities and find that air pollution regulation reduced pollution substantially. These regulations also led to a statistically insignificant decrease in infant mortality, though they note several data limitations that suggest their results should be interpreted with caution.

iii. Non-criteria pollutants

Most of the studies in Table 2 focus on so-called criteria pollutants, including ozone, particulate matter, carbon monoxide, nitrogen oxides, sulfur dioxide and lead, all of which are regulated under the Clean Air Acts in the U.S. Much less is known about other hazardous pollutants. Industrial plants in the U.S. emit approximately four billion pounds of toxic pollutants annually, including over 80,000 different chemical compounds (U.S. Gov. Account. Off. 2009). Regulation of these toxics is in its infancy and most have not undergone any form of toxicity testing (U.S. Cent. Dis. Control and Prev 2009). For example, it has been known for decades that mercury is highly toxic, yet the first regulation of mercury compounds in the United States - the Mercury and Airborne Toxics Standards was unveiled in December 2011.

Two studies have used U.S. county-level data from the EPA's Toxic Release Inventory to document a correlation between higher emissions and infant death (Currie \& Schmeider 2009; Agarwal et al. 2010). Currie et al. (2013a) further examined the effects of toxic emissions using openings and closures of more than 1,600 industrial plants that reported toxic emissions. By matching 1989-2003 data on 11 million individual birth records from five large states (Florida, Michigan, New Jersey, Pennsylvania, and Texas) with pollution monitor data, they first show that toxics can be detected up to a mile away from a plant, and that the "average" mother in these states lived within a mile of these plants. They then show that infants within a mile of a plant have a two percent higher incidence of low birth weight compared to infants one to two miles away, despite the fact that the two groups share equally 
in the economic benefits of plant operation. While housing values were also reduced, this only occurred within a half mile of a plant, suggesting that some people at risk of poor health outcomes are unaware of the hazards.

Another paper that moves beyond the consideration of criterion air pollutants is Sneeringer (2009), who examines pollution due to large-scale livestock operations. Although these operations have generated concerns regarding the pollution of water sources, animal wastes are also associated with the production of particulate matter as well as the non-criteria pollutants hydrogen sulfide gas and ammonia, all of which can be harmful to the developing fetus. She finds that a doubling of livestock production in a county is associated with an increase in infant mortality of 7.4\%. Although she cannot demonstrate a "first stage" effect of the operations on pollution, some evidence that the effect is primarily due to air pollution is obtained by examining causes of death (accidents and homicide vs. respiratory causes) and by comparing counties with high and low dependence on well water, which is more subject to contamination.

\section{Air Pollution and the Wellbeing of Older children}

Table 3 summarizes studies examining the effects of pollution on the health (Panel A) and cognitive outcomes (Panel B) of older children. Since there is no convenient summary measure of child health that is analogous to birth weight for infant health, most studies of child health focus on hospitalizations for respiratory infections or asthma. Respiratory ailments are a leading cause of hospitalizations among children, comparable in incidence only to injuries, which are unlikely to be influenced by pollution. ${ }^{10}$

Ransom \& Pope (1995) produced one of the first quasi-experimental studies of this type, using the closure of a local steel mill as a natural experiment. They found that child

\footnotetext{
${ }^{10}$ As such, injuries can serve as a useful ‘control’ condition for studies examining hospitalizations.
} 
hospitalizations for respiratory conditions fell when the mill was closed, and rebounded when the mill reopened. Since then a number of studies have been conducted making use of other clever natural experiments to identify the effects of pollution. Beatty \& Shimshack (2011) look at mandatory reductions in school bus emissions; Lleras-Muney (2010) examines children in military households who are exogenously assigned to areas with different pollution levels based on the needs of the military; Lavaine \& Neidell (2013) use strikes that shut down oil refineries in France; Yu (2011) studies a behavior modification experiment designed to reduce indoor air pollution from stoves; and Schlenker \& Walker (2011) use changes in pollution at California airports due to delays at east coast hubs. All of these papers find that reductions in pollution significantly reduced child respiratory problems.

The papers by Neidell (2004; 2009) highlight the importance of avoidance behavior, which is an issue for the interpretation of all of the studies discussed thus far (including those focusing on infants). People take actions ranging from changes in daily activities to moving house in order to reduce exposures to harmful pollutants. If people act to lessen their exposure, then the potentially harmful effects of pollution may be understated by estimation procedures that do not take these actions into account. A growing body of evidence suggests changes in daily actions effectively reduce exposure to pollution, even when those actions are not directly in response to poor air quality. Both Neidell papers find evidence that the effects of pollution exposure are much greater than is generally estimated when precautionary actions are ignored. Neidell also stress that such behaviours must be taken into account when calculating the costs of pollution.

Panel B of Table 3 illustrates the fact that there are many fewer studies of the effects of pollution on non-health child outcomes such as schooling attainment or test scores. This reflects both limitations on the available data and conceptual difficulties in elucidating the way pollution can be expected to affect test scores. For example, since test scores reflect 
cumulative knowledge, how should we account for the effects of cumulative exposure to pollution? In principal, the same issue applies to long-run health outcomes, but as discussed above, most of the research examining the effects of pollution on health outcomes has focused on relatively short-run effects (e.g. effects of in utero pollution on birth weight, or effects of pollution on hospitalizations for asthma).

One potential mechanism underlying an effect of pollution on test scores is through absence-if children are frequently absent from school because of high pollution levels, then this may interfere with their ability to learn. Currie et al. (2009a) find some evidence that higher pollution levels over six week attendance periods are associated with more student absences in Texas. Zweig et al. (2009) extend this analysis by using class-school-year level performance data to show that higher pollution levels decrease scores on annual achievement tests. To address concerns that differences in the student populations might be correlated with both pollution and lower test scores, they include school fixed effects as well as observable student and family characteristics in their analysis. Reyes (2011) does not have panel data, but shows a strong cross-sectional link between test scores in elementary schools in the 2000s and childhood lead levels in the same areas a decade earlier. Lavy et al. (2012) examine whether high pollution on the day of a high stakes test affects student performance. Using multiple test results for the same student and student fixed effects, they show that Israeli students earn lower scores when subjected to higher pollution on the day of the test.

\section{Effects of Water Pollution}

While the lion's share of studies on the effects of pollution on children is focused on air pollution, Table 4 provides a summary of the handful of studies that examine the effects 
of water pollution. ${ }^{11}$ One reason for the small number of studies is the primitive and fragmented state of water quality data relative to the data on air pollution. Whereas air quality monitoring in a given country is often undertaken by a single group or coalition of groups working together, such centralization is far less common for the monitoring of water quality. The scenario in the United States is not atypical, with the responsibility for monitoring water quality split between many programs, and the resulting information fragmented into many different incompatible databases. One database keeps track of permits for releasing chemicals into water bodies (the National Pollutant Discharge Information System); a second keeps track of toxic releases into the ground or surface water (the Toxic Release Inventory); a third records the results of mandatory periodic monitoring of public water systems (the Safe Drinking Water Information System); and a fourth samples water bodies for pollutants (the U.S. Geological Survey). Thus, it is extremely difficult to track a chemical released in one location to water ingested in another.

Currie et al. (2013b) examined the effects of chemical violations of drinking water quality standards in New Jersey from 1997 to 2007. Their data enabled the comparison of infants potentially exposed to contaminated drinking water in utero to siblings who were not. Using birth weight and gestation as outcomes, they found small effects of drinking water contamination for all infants, but large and statistically significant effects for infants born to less educated mothers. A potential explanation for this difference is that more educated mothers are more likely to be aware of the pollution and to take avoidance measures (Graff Zivin et al. 2011).

Troesken (2008) and Clay et al. (2010) look at the historic impact of lead from water pipes on infant health. In order to identify effects, both papers use the fact that in places where the water is more acidic, more lead leaches into drinking water from the pipes. The

\footnotetext{
${ }^{11}$ The Greenstone and Hanna paper mentioned earlier looked at the effects of water pollution regulation, but since they did not find any evidence of a first stage effect of regulation on pollution levels, it is not surprising that they found no effect of the regulation on health.
} 
papers show that although the installation of public water systems with lead pipes reduced deaths from disease, in many locations they increased infant deaths due to lead poisoning.

The paper by Brainerd \& Menon (2012) examines the impact of the runoff of agricultural chemicals into water supplies in India. The effects of the chemicals are identified using regional variations in crop cycles and rainfall. They find significant effects of this type of water pollution on infant mortality, child height-for-age and other measures. Similar to Currie et al. (2013b), they find larger effects among poorer households, which again is consistent with the idea that poorer households are less likely (or less able) to take measures to avoid pollution.

\section{Conclusions}

The research reviewed in this survey was motivated by two broader literatures spanning several academic fields. The first suggests that events in early life have effects that reach into adulthood. The second demonstrates that pollution, and especially discrete episodes of intense pollution such as the "London Fog” of 1952, has significant effects on health. Putting these observations together led researchers to probe this relationship directly. Does early-life exposure to pollution have long-term consequences later in life? The studies reviewed here provide strong evidence that they can. Like all good social science research this realization leads to a further set of questions:

First, can we identify threshold levels of particular chemicals that are "safe" for fetuses and young children? There is a preponderance of evidence that high levels of pollution (either historically in developed countries, or currently in developing countries) are

harmful. A particularly important question for policy is whether there is a safe level of these substances. A more subtle issue is that the thresholds may differ across groups. For example, children in developing countries may react more negatively to a given dose of 
pollution if they are already weakened due to other health shocks. Conversely, in an environment where the selective pressures of a hostile environment imply that only the strongest survive, a given dose of pollution could have milder effects.

Second, can we identify factors that protect against or exacerbate the effects of exposure? As we have stressed above, the extent to which parents are able to avoid exposure has important implications for the interpretation of the estimated effects of pollution. Whether parents can affect long run outcomes by remediating or exacerbating these early effects is similarly important.

Third, can we provide more evidence about how the effects of early life exposure to pollutants affect not only health, but other important economic outcomes such as education, labor force participation and earnings? Our survey of the literature suggested that relatively little has been done in this regard, particularly those that directly examine the long-run impacts of pollution exposure in early life. Quantifying effects on these outcomes is important for policy analysis.

Given the potentially long-lasting consequences from early exposure to pollution, the marginal returns to pollution control may be particularly high for this vulnerable segment of the population. As economists extend their reach into this arena and shed light on these key questions, this will better inform policy makers who must make significant decisions regarding the different approaches to pollution control. Together, they comprise an exciting and important research agenda. 


\section{Literature Cited}

1. Almond D, Currie J. 2011. Killing me softly: The fetal origins hypothesis.

J. of Econ. Perspect. 25(1):153-72

2. Almond D, Edlund L, Palme M. 2009. Chernobyl's subclinical legacy: Prenatal exposure to radioactive fallout and school outcomes in Sweden. Q. J. of Econ. 124(4):1729-72

3. Arceo-Gomez EO, Hanna R, Oliva P. 2012. Does the Effect of Pollution on Infant Mortality Differ Between Developing and Developed Countries? Evidence from Mexico City. Work. Pap., Nat. Bur. Econ. Res. No. 18349

4. Agarwal N, Banternghansa C, Bui L. 2010. Toxic exposure in America: Estimating fetal and infant health outcomes from 14 years of TRI reporting. J. of Health Econ. 29(4):557-74

5. Baccarelli A, Bollati V. 2009. Epigenetics and environmental chemicals. Curr. Opin. in Pediatrics. 21(2):243-51

6. Banzhaf SH, Walsh RP. 2008. Do people vote with their feet? An empirical test of Tiebout's mechanism. Am. Econ. Rev . 98(3):843-63

7. Barker DJ. 1990. The fetal and infant origins of adult disease. Br. Med. J. 301(6761):1111

8. Barnett WS. 1995. Long-term effects of early childhood programs on cognitive and school outcomes. The Future of Children, pp. 25-50

9. Bartik TJ. 1988. Evaluating the benefits of non-marginal reductions in pollution using information on defensive expenditures. J. of Enviro. Econ. and Manag. 15(1):111-27

10. Bateson TF, Schwartz J. 2007. Children's response to air pollutants. J. of Toxicol. and Environ. Health, Part A. 71(3):238-43

11. Beatty TK, Shimshack JP. 2011. School buses, diesel emissions, and respiratory health. J. of Health Econ. 30(5):987-99

12. Behrman JR, Rosenzweig MR, Taubman P. 1994, Endowments and the allocation of schooling in the family and in the marriage market: the twins experiment.

J. of Pol. Econ. 102(6)1131-74

13. Bharadwaj P, Gibson M, Graff Zivin J, Neilson C. 2013. Gray Matters: Pollution and Human Capital Formation. Work. Pap. 
14. Black SE, Butikofer A, Devereux PJ, Salvanes KG. 2013. This is only a test? Longrun impacts of prenatal exposure to radioactive downfall from nuclear weapon testing. Work. Pap

15. Bowen W. 2002. An analytical review of environmental justice research: what do we really know?. Environ. Manag. 29(1):3-15

16. Brainerd E, Menon N. 2012. Seasonal effects of water quality on infant and child health in India. Work. Pap. Institute for the Study of Labor (IZA)

17. Cesur R, Tekin E, Ulker A. 2013. Air pollution and infant mortality: Evidence from the expansion of natural gas infrastructure. Work. Pap., Nat. Bur. Econ. Res. No. 18736

18. Chay KY, Greenstone M. 2003a. Air quality, infant mortality, and the Clean Air Act of 1970. Work. Pap., Nat. Bur. Econ. Res. No. 10053

19. Chay KY, Greenstone M. 2003b. The impact of air pollution on infant mortality: evidence from geographic variation in pollution shocks induced by a recession. Q. $J$. of Econ. 118(3):1121-67

20. Clay K, Troesken W, Haines MR. 2010. Lead and mortality. Work. Pap., Nat. Bur. Econ. Res. No. 16480

21. Clinton WJ. April 21, 1997. Executive Order 13045: Protection of children from environmental health risks and safety risks. Federal Register. 62(2):19885

22. Coneus K, Spiess C. 2010. Pollution Exposure and infant health: Evidence from Germany. ZEW-Cent. for Eur. Econ. Res. Discuss. Pap. No. 10-079

23. Courant PN, Porter RC. 1981. Averting expenditure and the cost of pollution. J. of Enviro. Econ. and Manag. 8(1):321-9

24. Cropper M, Freeman AM III. 1991. Environmental health effects. In Measuring the Demand for Environmental Quality, ed. Braden JB, Kolstad CD, pp. 140-64. New York: Elsevier Science Publishing

25. Currie J. 2001.Early childhood education programs. J. of Econ. Perspect. 15(1):21338

26. Currie J. 2011. Inequality at birth: Some causes and consequences. Am. Econ. Rev . 101(3):1-22

27. Currie J, Almond D. 2011. Human capital development before age five. Handb. of Labor Econ. Volume 4:1315-486 
28. Currie J, Davis L, Greenstone M, Walker WR. 2013a. Do housing prices reflect environmental health risks? Evidence from more than 1600 toxic pant openings and closings. Work. Pap., Nat. Bur. Econ. Res. No. 16480

29. Currie J, Graff Zivin JS, Meckel K, Neidell MJ, Schlenker W. 2013b. Something in the water: Contaminated drinking water and infant health. Work. Pap., Nat. Bur. Econ. Res. No. 18876

30. Currie J, Greenstone M, Morettia E. 2011. Superfund cleanups and infant health. Am. Econ. Rev. 101(3):435-41

31. Currie J, Hanushek EA, Kahn EM, Neidell M, Rivkin SG. 2009a. Does pollution increase school absences?. Rev. of Econ. and Stat. 91(4):682-94

32. Currie J, Neidell M. 2005. Air pollution and infant health: What can we learn from California's recent experience?. Q. J. of Econ. 120(3):1003-30

33. Currie J, Neidell M, Schmieder JF. 2009b. Air pollution and infant health: Lessons from New Jersey. J. of Health Econ. 28(3):688-703

34. Currie J, Schmieder, JF. 2009. Fetal exposures to toxic releases and infant health. Am. Econ. Rev . 99(2):177-83

35. Currie J, Walker R. 2011. Traffic congestion and infant health: Evidence from EZPass. Am. Econ. J.: Appl. Econ. 3(1):65-90

36. Datar A, Kilburn MR, Loughran DS. 2010. Endowments and parental investments in infancy and early childhood. Demography. 47(1):145-62

37. deRegnier RA, Desai S. 2010. Fetal Development. In The Wiley-Blackwell Handbook of Infant Development, ed. Bremmer JG, Wachs TD. (2):9-32. Wiley-Blackwell. 2nd ed.

38. Deschênes O, Greenstone M, Shapiro JS. 2012. Defensive investments and the demand for air quality: Evidence from the NOx budget program and ozone reductions. Work. Pap., Nat. Bur. Econ. Res. No. 18276

39. Engle, P. (2010). Infant development in the developing world. In The Wiley-Blackwell Handbook of Infant Development, ed. Bremmer JG, Wachs TD. (2):140-64. WileyBlackwell. 2nd ed.

40. Evans GW. 2006. Child development and the physical environment. Annu. Rev. Psychol. (57):423-51

41. Foster A, Gutierrez E, Kumar N. 2009. Voluntary compliance, pollution levels, and infant mortality in Mexico. Am. Econ. Rev. Pap. and Proc. 99(2):191-7 
42. Gluckman PD, Hanson MA, Cooper C, Thornburg KL. 2008. Effect of in utero and early-life conditions on adult health and disease. N. Engl. J. of Med. 359(1):61-73

43. Graff Zivin J, Neidell M. 2013. Environment, health, and human capital. Work. Pap., Nat. Bur. Econ. Res. No. 18935

44. Graff Zivin J, Neidell M, Schlenker W. 2011. Water quality violations and avoidance behavior: Evidence from bottled water consumption. Am. Econ. Rev. Pap. and Proc. 101: 448-53

45. Greenstone M, Hanna R. 2011. Environmental regulations, air and water pollution, and infant mortality in India. Work. Pap., Nat. Bur. Econ. Res. No. 17210

46. Grossman M. 1972. On the concept of health capital and the demand for health. The Journal of Political Economy 80(2): 223-255.

47. Harrington W, Portney PR. 1987. Valuing the benefits of health and safety regulation. J. of Urban Econ. 22(1):101-12

48. Heckman JJ. 2000. Policies to foster human capital. Res. in Econ. 54(1):3-56

49. Cunha F, Heckman JJ . 2007. "The Technology of Skill Formation," American Economic Review, 97(2):31-47.

50. Holt PG. 1998. Programming for responsiveness to environmental antigens that trigger allergic respiratory disease in adulthood is initiated during the perinatal period. Environ. Health Perspect. 106(3):795-800

51. Isen A, Rossin-Slater M, Walker WR. 2013. Every breath you take—Every dollar you'll make: The long-term consequences of the Clean Air Act of 1970. Work. Pap.

52. Janke K, Propper C, Henderson J. 2009. Do current levels of air pollution kill? The impact of air pollution on population mortality in England. Health Econ. 18(9):103155

53. Jayachandran S. 2009. Air quality and early-life mortality evidence from Indonesia's wildfires. J. of Hum. Resour. 44(4):916-54

54. Knittel CR, Miller DL, Sanders NJ. 2011. Caution, drivers! Children rresent: Traffic, pollution, and infant health. Work. Pap., Nat. Bur. Econ. Res. No. 17222

55. Lavaine E, Neidell MJ. 2013. Energy production and health externalities: Evidence from oil refinery strikes in France. Work. Pap., Nat. Bur. Econ. Res. No. 18974

56. Lavy V, Ebenstein A, Roth S. 2012. The Impact of air pollution on cognitive performance and human capital formation. Work. Pap. 
57. Lleras-Muney A. 2010. The needs of the army: Using compulsory relocation in the military to estimate the effect of air pollutants on children's health. J. of Hum. Resour. 45(3):549-90

58. Lüchinger S. 2010. Air pollution and infant mortality: A natural experiment from power plant desulfurization. Work. Pap.

59. Makri A, Goveia M, Balbus J, Parkin R. 2004. Children's susceptibility to chemicals: a review by developmental stage. J. of Toxicol. and Environ. Health, Part B. 7(6):417-35

60. Neidell MJ. 2009. Information, Avoidance behavior, and health the effect of ozone on asthma hospitalizations. J. of Hum. Resour. 44(2):450-78

61. Neidell MJ. 2004. Air pollution, health, and socio-economic status: the effect of outdoor air quality on childhood asthma. J. of Health Econ. 23(6):1209-36

62. Nilsson JP. 2009. The long-term effects of early childhood lead exposure: Evidence from the phase-out of leaded gasoline. Work. Pap., Inst. for Labour Mark. Policy Eval.

63. Parker JD, Mendola P, Woodruff TJ. 2008. Preterm birth after the Utah Valley Steel Mill closure: a natural experiment. Epidemiology. 19(6):820-3

64. Petronis A. 2010. Epigenetics as a unifying principle in the aetiology of complex traits and diseases. Nature. 465(7299):721-727

65. Pope CA III. 1989. Respiratory disease associated with community air pollution and a steel mill, Utah Valley. Am. J. of Pub. Health. 79(5):623-8

66. Pope CA III, Schwartz J, Ransom MR. 1992. Daily mortality and PM10 pollution in Utah Valley. Archives of Environmental Health. 47(3):211-7

67. Ransom MR, Pope CA. 1995. External health costs of a steel mill. Contemp. Econ. Policy. 13(2):86-97

68. Rauch SA, Lanphear BP. 2012. Prevention of disability in children: Elevating the role of environment. The Future of Children. 22(1):193-217

69. Rauh VA, Garfinkel R, Perera FP, Andrews HF, Hoepner L, et al. 2006. Impact of prenatal chlorpyrifos exposure on neurodevelopment in the first 3 years of life among inner-city children. Pediatrics. 118(6):e1845-59

70. Reyes JW. 2012. Lead exposure and behavior: Effects on antisocial and risky behavior among children and adolescents. Work. Pap. 
71. Reyes JW. 2011. Childhood lead and academic performance in Massachusetts. Work. Pap., N. Engl. Pub. Pol. Cen.

72. Reyes JW. 2007. Environmental policy as social policy? The impact of childhood lead exposure on crime. B.E. J. of Econ. Anal. and Pol. 7(1) (Contributions), Article 51

73. Sanders NJ. 2012. What doesn't kill you makes you weaker prenatal pollution exposure and educational outcomes. J. of Hum. Resour. 47(3):826-50

74. Sanders NJ, Stoecker CF. 2011. Where have all the young men gone? Using gender ratios to measure fetal death rates. Work. Pap., Nat. Bur. Econ. Res. No. 17434

75. Schlenker W, Walker WR. 2011. Airports, air pollution, and contemporaneous health. Work. Pap., Nat. Bur. Econ. Res. No. 17684

76. Schwartz J. 2004. Air pollution and children's health. Pediatrics. 113(3):1037-43

77. Schweinhart L, Barnes HV, Weikart DP. 1993. Significant benefits: The High-Scope Perry Preschool study through age 27. Ypsilanti, MI: HighScope Press

78. Schweinhart LJ, Montie J, Xiang Z, Barnett WS, Belfield CR, Nores M. Lifetime effects: the High/Scope Perry Preschool study through age 40. Ypsilanti, MI: HighScope Press

79. Sneeringer S. 2009. Does animal feeding operation pollution hurt public health? A national longitudinal study of health externalities identified by geographic shifts in livestock production. Am. J. of Agric. Econ. 91(1):124-37

80. Sullivan D, Von Wachter T. 2009. Job displacement and mortality: An analysis using administrative data. Q. J. of Econ. 124(3):1265-06

81. Tiebout CM. 1956. A pure theory of local expenditures. J. of Pol. Econ. 64(5):416-24

82. Troesken W. 2008. Lead water pipes and infant mortality at the turn of the twentieth century. J. of Hum. Resour. 43(3):553-75

83. U.S. Cent. Dis. Control and Prev. 2009. Fourth report on human exposure to environental chemicals

84. U.S. Environ. Prot. Agency. 2013. America's children and the environment, Third Edition

85. U.S. Gov. Account. Off. 2009. Observations on improving the Toxic Substance Control Act

86. Yu F. 2011. Indoor air pollution and children's health: Net benefits from stove and behavioral interventions in rural China. Environ. and Resource Econ. 50(4):495-514 
87. Zhang J. 2012. The impact of water quality on health: Evidence from the drinking water infrastructure program in rural China. J. of Health Econ. 31(1):122-34

88. Zweig SJ, Ham CJ, Avol LE. 2009. Air pollution and academic performance: Evidence from California schools. Work. Pap. 
Table 1: Studies of air pollution and long term outcomes

\begin{tabular}{|c|c|c|c|}
\hline $\begin{array}{c}\text { Paper / Country / } \\
\text { Source of } \\
\text { Variation }\end{array}$ & Methods & Data/Size & Outcomes \\
\hline $\begin{array}{l}\text { Almond et al. } \\
\text { (2009) } \\
\text { Sweden } \\
\text { Chernobyl Disaster }\end{array}$ & $\begin{array}{l}\text { OLS approach is used to measure } \\
\text { outcomes of those exposed against } \\
\text { a number of comparison groups. } \\
\text { Additionally, a D-in-D approach } \\
\text { was used to examine compensatory } \\
\text { behavior effects on impacted } \\
\text { children. Both approaches include } \\
\text { a wide set of controls. }\end{array}$ & $\begin{array}{l}\text { Outcomes (birth, health, school, \& } \\
\text { hospitalizations) data on Swedish } \\
\text { birth cohorts from 1983-1988 are } \\
\text { linked with radiation data collected } \\
\text { from ground monitors and a } \\
\text { country wide aerial survey of } \\
\text { ground deposition in } 1986 \text {. } \\
\text { Analysis is at the child level. There } \\
\text { are >500k observations used with } \\
\text { the aerial exposure data, and } ~ 170 \mathrm{k} \\
\text { when in situ measurements are } \\
\text { examined. }\end{array}$ & $\begin{array}{l}\text { Significant reductions of } 2.5 \\
\text { percentile points for average } \\
\text { grades, and } 6 \% \text { for math grades } \\
\text { measured in secondary school for } \\
\text { children most highly exposed to } \\
\text { fallout in utero (ages } 8-25 \text { weeks). } \\
\text { Impacts strongest among those } \\
\text { likely to have faced higher } \\
\text { exposure levels and to children of } \\
\text { low income parents. No } \\
\text { corresponding long-term health } \\
\text { effects are found. }\end{array}$ \\
\hline $\begin{array}{l}\text { Bharadwaj et al. } \\
\text { (2013) } \\
\text { Chile } \\
\text { Variation in } \\
\text { ambient pollution } \\
\text { during gestational } \\
\text { development is } \\
\text { used for } \\
\text { identification }\end{array}$ & $\begin{array}{l}\text { 4th and 8th grade test outcomes are } \\
\text { regressed on mean ambient } \\
\text { pollutant levels in each of the } 9 \\
\text { months of gestation and a large } \\
\text { number of controls and fixed } \\
\text { effects. Controls for monthly } \\
\text { weather during gestation are } \\
\text { included, as are mother } \\
\text { demographic controls and } \\
\text { community and gender fixed } \\
\text { effects. }\end{array}$ & $\begin{array}{l}\text { Test scores - in math, science, and } \\
\text { language arts - for approximately } \\
600 \mathrm{k} \text { children are linked to } \\
\text { monthly average pollution in the } \\
\text { Santiago Metropolitan Region } \\
\text { during each month of gestation. } \\
\text { Pollution and weather data are } \\
\text { taken from the Ministry of } \\
\text { Environment and the NOAA } \\
\text { summary of the day respectively, } \\
\text { while test scores and child/family } \\
\text { data are provided by the Chilean } \\
\text { Health Ministry. }\end{array}$ & $\begin{array}{l}\text { A } 1 \text { SD increase in Ozone levels } \\
\text { during the 3rd month of pregnancy } \\
\text { leads to } 0.0025 \text { and } 0.00173 \text { SD } \\
\text { reductions in } 4 \text { th grade math and } \\
\text { language test scores respectively. } \\
\text { Effects are broadly similar for 8th } \\
\text { grade test performance. }\end{array}$ \\
\hline $\begin{array}{l}\text { Currie et al. } \\
\text { (2013b) } \\
\text { United States } \\
\text { Differential in } \\
\text { utero exposure to } \\
\text { drinking water } \\
\text { contamination } \\
\text { violations between } \\
\text { siblings is used for } \\
\text { identification }\end{array}$ & $\begin{array}{l}\text { A number of later life outcomes } \\
\text { (IQ, height, years of education, } \\
\text { high school completion and } \\
\text { earnings at 35) are regressed on } \\
\text { potential fallout exposure in } \\
\text { municipality of mother's residence } \\
\text { during weeks 8-16 of the } \\
\text { pregnancy, as well as a number of } \\
\text { parental and child controls, and } \\
\text { municipality and month of birth } \\
\text { fixed effects. Other specifications } \\
\text { also include municipality trends, } \\
\text { family fixed effects, and two } \\
\text { measures of fallout included } \\
\text { simultaneously. }\end{array}$ & $\begin{array}{l}\text { Later life outcomes for } \sim 400 \mathrm{k} \\
\text { individuals in the birth cohorts of } \\
\text { 1956-1966 are linked to } \\
\text { measurements from } 13 \text { fallout test } \\
\text { stations to estimate monthly fallout } \\
\text { levels (measured in the air and } \\
\text { deposited) by municipality (for } \\
\text { those within } 20 \text { km of a test } \\
\text { station) while individuals were in } \\
\text { utero. }\end{array}$ & $\begin{array}{l}1 \text { SD increase in ground exposure } \\
\text { is associated with a } 0.025 \text { SD } \\
\text { decrease in IQ score, } \sim 0.15 \text { fewer } \\
\text { years of education, and } 0.1 \text { to } 0.25 \\
\text { log point reduction in earnings at } \\
\text { age } 30 \text {. Even wealthy families are } \\
\text { unable to avoid such impacts. } \\
\text { Largest in utero effects are found } \\
\text { for exposures during weeks } 8 \text { to } \\
16 \text {. }\end{array}$ \\
\hline $\begin{array}{l}\text { Isen et al. (2013) } \\
\text { United States } \\
\text { Differential } \\
\text { changes in TSPs by } \\
\text { county due to non- } \\
\text { attainment status } \\
\text { under the Clean Air } \\
\text { Act Amendments } \\
\text { of } 1970\end{array}$ & $\begin{array}{l}\text { Non-attainment status of counties } \\
\text { is assigned based on observed TSP } \\
\text { levels, and is then used to } \\
\text { instrument for a large change in } \\
\text { TSP in counties identified as non- } \\
\text { attainers. A difference-in- } \\
\text { differences analysis is then run } \\
\text { comparing changes in outcomes to } \\
\text { those born in non-attainment vs. } \\
\text { attainment counties before and } \\
\text { after the } 1971 \text { implementation of } \\
\text { the } 1970 \text { CAAAs. Regressions are } \\
\text { weighted by \# of workers. }\end{array}$ & $\begin{array}{l}\text { Earnings records for } 24 \text { states from } \\
\text { 1998-2007 - from the Longitudinal } \\
\text { Employer Household Dynamics } \\
\text { File - are merged with county and } \\
\text { date of birth, and county level } \\
\text { annual average and 2nd max } \\
\text { observed TSP levels. In total, } \\
\text { 900k individuals are included in } \\
\text { the analysis in } 888 \text { county/year } \\
\text { observations. }\end{array}$ & $\begin{array}{l}\text { A } 1 \% \text { increase in annual salaries of } \\
\text { workers aged } 29-31 \text { is attributed to } \\
\text { a } 10 \mu \mathrm{g} / \mathrm{m} 3 \text { unit decrease in TSP } \\
\text { during pregnancy and early } \\
\text { childhood. Most of this effect is } \\
\text { due to increased workforce } \\
\text { participation. The CAAA of } 1970 \\
\text { lead to an average increase in } \\
\text { lifetime earnings of } \$ 4,300 \text { for the } \\
1.5 \text { million children born in non- } \\
\text { attainment counties each year. }\end{array}$ \\
\hline
\end{tabular}


Table 1: Studies of air pollution and long term outcomes - Cont'd

\begin{tabular}{|c|c|c|c|}
\hline $\begin{array}{c}\text { Paper / Country / } \\
\text { Source of } \\
\text { Variation }\end{array}$ & Methods & Data/Size & Outcomes \\
\hline $\begin{array}{l}\text { Nilsson (2009) } \\
\text { Sweden } \\
\text { Geographic } \\
\text { variation in } \\
\text { reduction of lead } \\
\text { levels due to phase } \\
\text { out of leaded } \\
\text { gasoline }\end{array}$ & $\begin{array}{l}\text { OLS regressions are estimated for } \\
\text { many outcome variables, } \\
\text { regressing the outcome on lead } \\
\text { exposure, an exceedingly rich set } \\
\text { of parental, child, and municipality } \\
\text { specific characteristics, and finally } \\
\text { fixed effects for year of birth and } \\
\text { municipality of birth. Conditional } \\
\text { on the municipality fixed effects } \\
\text { parental outcomes are not } \\
\text { predictive of a child's lead } \\
\text { exposure. }\end{array}$ & $\begin{array}{l}\text { Ambient lead levels for } 1,000 \\
\text { locations around Sweden in } 1975 \text {, } \\
\text { 1980, and } 1985 \text { from moss samples } \\
\text { are aggregated to provide } \\
\text { municipality-level estimates of } \\
\text { lead exposure. This data is linked } \\
\text { to socio-economic and outcome } \\
\text { variables for children born in the } 3 \\
\text { years preceding each of the lead } \\
\text { samples. Outcomes examined } \\
\text { include high school GPA and test } \\
\text { scores, high school completion and } \\
\text { educational attainment, labor } \\
\text { market earnings and teenage } \\
\text { motherhood. Sample sizes range } \\
\text { from 250k to } ~ 800 k \text { individuals. }\end{array}$ & $\begin{array}{l}\text { A significant and non-linear } \\
\text { relationship is shown between } \\
\text { municipality air lead levels in early } \\
\text { childhood and young adult } \\
\text { outcomes. Significant } \\
\text { improvements in young adult } \\
\text { outcomes were found for the } \\
\text { reduction in air lead levels } \\
\text { obtained between } 1972 \text { and } 1984 \\
\text { in Sweden, but no significant } \\
\text { effects of further reductions were } \\
\text { found below estimated blood-lead } \\
\text { levels of } 5 \mu \text { g/dL. Study also finds } \\
\text { that low-SES children are affected } \\
\text { more for any given amount of lead } \\
\text { exposure, and that this effect is not } \\
\text { solely due to residential } \\
\text { segregation. }\end{array}$ \\
\hline $\begin{array}{l}\text { Reyes (2007) } \\
\text { United States } \\
\text { State specific } \\
\text { reduction in lead } \\
\text { exposure due to } \\
1970 \text { Clean Air Act } \\
\text { removal of Lead } \\
\text { from gasoline }\end{array}$ & $\begin{array}{l}\text { The implied first stage is supported } \\
\text { with OLS regressions showing that } \\
\text { gasoline lead and air lead are good } \\
\text { predictors of child blood lead. The } \\
\text { main specification is a state-level } \\
\text { regression of logged per capita } \\
\text { crime rates (violent, property, and } \\
\text { murders are run separately) for the } \\
\text { years of 1985-2002 on effective } \\
\text { lead exposure (estimated from } \\
\text { gasoline lead levels during ages 0- } \\
3 \text { of the average age of arrested } \\
\text { cohorts), state dummies, and a } \\
\text { large number of additional } \\
\text { covariates that might be thought to } \\
\text { impact crime rates. }\end{array}$ & $\begin{array}{l}\text { Creates state-year Lead exposure } \\
\text { estimates from EPA monitor data } \\
\text { and measures of Lead per gallon of } \\
\text { gasoline by state and year from } \\
\text { DOE and private annual reports. } \\
\text { Exposure estimates are linked to } \\
\text { crime and National Health Survey } \\
\text { data by state and year. The } 918 \\
\text { observations include } 50 \text { states plus } \\
\text { D.C. for 1985-2002, and are } \\
\text { weighted by population in the } \\
\text { analysis. }\end{array}$ & $\begin{array}{l}\text { A significant relationship between } \\
\text { lead exposure in childhood, and } \\
\text { violent crime rates later in life is } \\
\text { demonstrated with an estimate of } \\
0.8 \text { for the elasticity of violent } \\
\text { crime to childhood lead exposure. } \\
\sim 56 \% \text { of the drop in violent crime } \\
\text { observed in the U.S. in the } 1990 \text { s } \\
\text { can be attributed to reductions in } \\
\text { lead exposure during the } 1970 \text { s. } \\
\text { The effects are focused on violent } \\
\text { crimes. }\end{array}$ \\
\hline $\begin{array}{l}\text { Sanders (2012) } \\
\text { United States } \\
\text { Early 1980s } \\
\text { Recession and } \\
\text { related drops in } \\
\text { manufacturing } \\
\text { employment }\end{array}$ & $\begin{array}{l}\text { OLS and 2SLS link changes in } \\
\text { year of birth average TSP at the } \\
\text { county level and changes in } \\
\text { average performance on a 10th } \\
\text { grade standardized tests at the } \\
\text { school level. TSP measures are } \\
\text { used both directly, and also } \\
\text { instrumented using county-level } \\
\text { employment changes in } \\
\text { manufacturing. School-level and } \\
\text { year-of-birth-by-year-of-test fixed } \\
\text { effects are included as well as } \\
\text { controls for school-level student } \\
\text { characteristics, county-level } \\
\text { weather, and } \\
\text { economic/demographic } \\
\text { characteristics in year of birth and } \\
\text { year of test. In the IV specification } \\
\text { where manufacturing jobs are used } \\
\text { to instrument for TSP, county-level } \\
\text { income is also instrumented using } \\
\text { national crude oil prices. }\end{array}$ & $\begin{array}{l}\text { TSP measures from EPA monitors } \\
\text { are aggregated to the county-year } \\
\text { level for 1979-1985, and merged } \\
\text { with weather data from the Global } \\
\text { Surface Summary. Employment, } \\
\text { income, population, and density } \\
\text { data are added from the Regional } \\
\text { Information System, and test } \\
\text { scores for } 1994-200210 \text { th grade } \\
\text { cohorts are provided from the } \\
\text { Texas Education Agency. Sample } \\
\text { sizes are } 100 k \text { students per year } \\
\text { born in } 1979-1985 \text { at } 416 \text { schools } \\
\text { in } 30 \text { counties. }\end{array}$ & $\begin{array}{l}\text { OLS regressions suggest that a } 1 \\
\text { SD reduction in TSP during the } \\
\text { year of birth is associated with a } \\
2 \% \text { of a SD increase in 10th grade } \\
\text { test scores. The IV estimates yield } \\
\text { a } 6 \% \text { of a SD increase in test } \\
\text { scores (and a } 3 \% \text { increase in } \\
\text { county passing rates) from a } 1 \text { SD } \\
\text { reduction in TSPs. }\end{array}$ \\
\hline
\end{tabular}


Table 2: Studies of air pollution, fetal health, and infant mortality

\begin{tabular}{|c|c|c|c|}
\hline $\begin{array}{c}\text { Paper / Country / } \\
\text { Source of } \\
\text { Variation }\end{array}$ & Methods & Data/Size & Outcomes \\
\hline $\begin{array}{l}\text { Arceo-Gomez et al. } \\
(2012) \\
\text { Mexico } \\
\text { Week-to-week } \\
\text { meteorological } \\
\text { covariation with } \\
\text { cyclical air } \\
\text { pollution changes } \\
\text { is used for } \\
\text { identification }\end{array}$ & $\begin{array}{l}\text { Weekly levels of pollution and } \\
\text { infant death by municipality in } \\
\text { Mexico City are analyzed using } \\
\text { municipality fixed effects. Main } \\
\text { results are IV using \# of days of } \\
\text { inversion layer per week to } \\
\text { instrument for air pollution. An } \\
\text { additional inversion is associated } \\
\text { with 3.5\% increase in PM and } \\
5.4 \% \text { increase in CO. }\end{array}$ & $\begin{array}{l}\text { For the period from 1997-2006, } \\
\text { weekly average levels of pollution, } \\
\text { infant and neonatal mortality, and } \\
\text { number of inversions are } \\
\text { calculated for each of Mexico } \\
\text { City's } 56 \text { Municipalities. Pollution } \\
\text { values are interpolated from } \\
\text { observations at 10-26 stations } \\
\text { (depending on availability) and } \\
\text { inversions are ID'd in Ministry of } \\
\text { the Environment data. }\end{array}$ & $\begin{array}{l}\text { 1ppb more CO leads to } .0032 \text { more } \\
\text { infant deaths per } 100,000 \text { births, } \\
\text { and } 1 \text { extra } \mu \mathrm{g} / \mathrm{m} 3 \text { results in } 0.24 \\
\text { more infant deaths per } 100,000 \\
\text { births. } \mathrm{PM}_{10} \text { effects are similar } \\
\text { while the CO impacts are larger. }\end{array}$ \\
\hline $\begin{array}{l}\text { Agarwal et al. } \\
(2010) \\
\text { United States } \\
\text { Variation in } \\
\text { chemical releases } \\
\text { is utilized for } \\
\text { identification }\end{array}$ & $\begin{array}{l}\text { A WLS approach regressing } \\
\text { county demeaned outcome } \\
\text { variables on concentrations of } \\
\text { toxic releases, time fixed effects, } \\
\text { and controls for parental and } \\
\text { county level covariates. }\end{array}$ & $\begin{array}{l}\text { Annual Toxic Release Inventory } \\
\text { (TRI) data on toxic chemical } \\
\text { releases by manufacturing site are } \\
\text { aggregated to the county level and } \\
\text { merged with county level infant } \\
\text { fetal mortality rates in the United } \\
\text { States for } 1989 \text { to } 2002 .>40,000 \\
\text { county/year observations, of } \\
\text { which } 4000 \text { have air pollution } \\
\text { data allowing controls for ambient } \\
\text { PM }_{10} \text { and Ozone levels. }\end{array}$ & $\begin{array}{l}\text { Reductions of annual toxic } \\
\text { chemical releases are estimated to } \\
\text { have lead to approximately } 11,694 \\
\text { saved infant lives over the study } \\
\text { period, which the authors estimate } \\
\text { (using a } \$ 1.8 \mathrm{M}<\mathrm{VSL}<\$ 8.7 \mathrm{M} \text { ) } \\
\text { provided a cost savings of } \$ 21 \mathrm{~B} \text { to } \\
\$ 101 \mathrm{~B} \text {. }\end{array}$ \\
\hline $\begin{array}{l}\text { Currie et al. } \\
(2013 b) \\
\text { United States } \\
\text { Differential in } \\
\text { utero exposure to } \\
\text { drinking water } \\
\text { contamination } \\
\text { violations between } \\
\text { siblings is used for } \\
\text { identification }\end{array}$ & $\begin{array}{l}\text { Difference-in-difference is used to } \\
\text { link changes in TSP levels to infant } \\
\text { health outcomes, comparing } \\
\text { changes in infant mortality } \\
\text { between non-attainment counties } \\
\text { and others. Additionally, the } \\
\text { analysis uses non-attainment status } \\
\text { as an instrumental variable for TSP } \\
\text { declines from } 1971 \text { to 1972, and a } \\
\text { regression discontinuity } \\
\text { comparison is made of counties } \\
\text { just above and below the non- } \\
\text { attainment threshold. }\end{array}$ & $\begin{array}{l}\text { County-level data on infant health, } \\
\text { air pollution, and other } \\
\text { characteristics for the period from } \\
\text { 1969-1974. Data comes from the } \\
\text { National Mortality and Natality } \\
\text { Detail Files, the EPA, the Bureau } \\
\text { of Economics Analysis, and the } \\
\text { Regional Economics Information } \\
\text { System. A panel of } 501 \text { counties is } \\
\text { created for the analysis. }\end{array}$ & $\begin{array}{l}\text { The majority of TSP reductions } \\
\text { occurred in non---attainment } \\
\text { counties. A } 1 \% \text { reduction in } \\
\text { ambient average TSPs in a county } \\
\text { led to a } 0.5 \% \text { fall in the infant } \\
\text { mortality rate in the county. }\end{array}$ \\
\hline $\begin{array}{l}\begin{array}{l}\text { Chay and } \\
\text { Greenstone } \\
(2003 b)\end{array} \\
\text { United States } \\
\text { 1981-82 recession } \\
\text { and resulting } \\
\text { differential } \\
\text { reductions in TSPs } \\
\text { between counties }\end{array}$ & $\begin{array}{l}\text { First differences are used to } \\
\text { identify effects from cross-county, } \\
\text { intra-state variation in pollution } \\
\text { reductions due to the recession } \\
\text { taking into account a rich set of } \\
\text { covariates. Counties with "large" } \\
\text { and "medium" changes in TSPs are } \\
\text { also compared separately to } \\
\text { counties with "small" changes to } \\
\text { investigate non-linearity of health } \\
\text { impacts from TSPs. }\end{array}$ & $\begin{array}{l}\text { Data from the Census, Bureau of } \\
\text { Economic Analysis, National } \\
\text { Mortality Detail Files, and } \\
\text { National Natality Detail Files are } \\
\text { merged and aggregated to the } \\
\text { county level. Observations were } \\
\text { then matched with EPA monitor } \\
\text { data which provided approximated } \\
1200 \text { county-years of data between } \\
\text { 1978-1984. }\end{array}$ & $\begin{array}{l}\text { One percent reduction in TSP } \\
\text { levels is associated with a } 0.35 \\
\text { percent reduction in infant } \\
\text { mortality at the county level. } \\
\text { Nationwide, this suggests that the } \\
\text { recession lead to } 2500 \text { fewer } \\
\text { infant deaths during the years of } \\
\text { 1980-1982. Health effects are non- } \\
\text { linear in TSP exposure. }\end{array}$ \\
\hline
\end{tabular}


Table 2: Studies of air pollution, fetal health, and infant mortality - Cont'd

\begin{tabular}{|c|c|c|c|}
\hline $\begin{array}{c}\text { Paper / Country / } \\
\text { Source of } \\
\text { Variation }\end{array}$ & Methods & Data/Size & Outcomes \\
\hline $\begin{array}{l}\text { Coneus and Spiess } \\
\text { (2010) } \\
\text { Germany } \\
\text { Cross time and } \\
\text { location variation } \\
\text { in pollutant levels } \\
\text { used for } \\
\text { identification }\end{array}$ & $\begin{array}{l}\text { Mother Fixed Effects models with } \\
\text { year-zip code effects as well as } \\
\text { limited sets of covariates are } \\
\text { estimated for a number of health } \\
\text { outcomes for both infants and 2-3 } \\
\text { year olds ."Indoor air pollution" } \\
\text { proxied for by cigarette use. } \\
\text { Models are estimated for pollution } \\
\text { at birth, during pregnancy, and for } \\
\text { latent values during pregnancy and } \\
\text { longer term exposure variables for } \\
\text { the older children. Outcome } \\
\text { variables include a number of } \\
\text { physical developmental measures } \\
\text { and illness indicators. Observation } \\
\text { level is child/quarter. }\end{array}$ & $\begin{array}{l}\text { Data from the German Socio- } \\
\text { Economic Panel (SOEP) on socio- } \\
\text { economic conditions and health of } \\
\text { newborns and } 2-3 \text { year olds in the } \\
\text { birth cohorts from } 2002-2007 \text { is } \\
\text { merged with data on total- } \\
\text { pregnancy, trimester-specific, at- } \\
\text { birth, and first-year-of-life } \\
\text { pollution levels from observations } \\
\text { of the } 5 \text { pollutants of interest from } \\
\text { Germany's Federal Environment } \\
\text { Agency. Cohort sizes are } 1100 \\
\text { newborns and } ~ 7002-3 \text { year olds } \\
\text { per year. }\end{array}$ & $\begin{array}{l}\text { CO has negative impacts on birth } \\
\text { and health outcomes (esp. in 3rd } \\
\text { trimester). High exposure to CO } \\
\text { leads to a } 289 \text { g lower birthweight. } \\
\text { Marginally significant results for } \\
\text { Ozone and high levels of } \mathrm{NO}_{2} \text { and } \\
\mathrm{SO}_{2} \text { through pregnancy. In utero } \\
\text { exposure to PM } \mathrm{M}_{10} \text { is not found to } \\
\text { have negative impacts. Ozone } \\
\text { exposure at a young age is } \\
\text { correlated with negative health } \\
\text { outcomes - such as a } 0.70 \% \\
\text { increase in bronchitis with a one } \\
\text { unit increase in the 3-year average } \\
\mathrm{O}_{3} \text { level - as is exposure to PM } \\
\text { (although less robustly), while no } \\
\text { clear relationships are found } \\
\text { between early-life CO, } \mathrm{SO}_{2} \text {, or } \\
\mathrm{NO}_{2} \text { exposure and the health } \\
\text { outcomes studied. }\end{array}$ \\
\hline $\begin{array}{l}\text { Currie et al. (2011) } \\
\text { United States } \\
\text { Superfund site } \\
\text { cleanup }\end{array}$ & $\begin{array}{l}\text { Difference-in-Differences analysis } \\
\text { comparing the change in birth } \\
\text { outcomes before and after } \\
\text { Superfund site cleanup for mothers } \\
\text { within } 2 \mathrm{~km} \text { of the site to mothers } \\
\text { between } 2 \text { and } 5 \mathrm{~km} \text { of the site. A } \\
\text { broad set of mother and child } \\
\text { covariates are included and site- } \\
\text { level or zip-code fixed effects are } \\
\text { also included in some } \\
\text { specifications. Additional analyses } \\
\text { are run for a subset of the most } \\
\text { contaminated Superfund sites. }\end{array}$ & $\begin{array}{l}\text { Florida, Michigan, New Jersey, } \\
\text { Pennsylvania, and Texas births } \\
\text { between } 1989 \text { and } 2003 \text { with } \\
\text { mother addresses within } 5 \mathrm{~km} \text { of a } \\
\text { Superfund site that was cleaned up. } \\
154 \text { sites are included in the } \\
\text { analysis providing } ~ 600 \mathrm{k} \text { mothers } \\
\text { in the sample, of which } 92 \mathrm{k} \text { lived } \\
\text { within } 2 \mathrm{~km} \text { of a cleaned up site. }\end{array}$ & $\begin{array}{l}\text { Following clean ups, significant } \\
\text { reductions (from 20-25\%) in } \\
\text { congenital anomalies to mothers } \\
\text { living within } 2 \text { km of a site are } \\
\text { observed. Also, when only a } \\
\text { subsample of the most } \\
\text { contaminated sites is used, } \\
\text { significant ( } 4.5 \text { deaths per } 1,000 \\
\text { live births) reductions in infant } \\
\text { death are found across } \\
\text { specifications, authors note this } \\
\text { result seems too large and may be } \\
\text { due partly to sorting. }\end{array}$ \\
\hline $\begin{array}{l}\text { Currie and Neidell } \\
\text { (2005) } \\
\text { United States } \\
\text { Inter-temporal } \\
\text { variation in } \\
\text { pollution and infant } \\
\text { health are used to } \\
\text { identify effects }\end{array}$ & $\begin{array}{l}\text { Pollution levels are assigned to zip } \\
\text { codes by weighting monitor } \\
\text { averages for monitors within } 20 \\
\text { miles with the inverse of the } \\
\text { monitor's distance to the zip code } \\
\text { center. A discrete-time hazard } \\
\text { model is estimated with a linear } \\
\text { spline in duration and pollution } \\
\text { exposure measures for all } 3 \\
\text { pollutants at } 1,2 \text {, } 4,8,12,20 \text {, and } \\
32 \text { weeks of life. Infant death is } \\
\text { also regressed on these pollution } \\
\text { measures as well as average } \\
\text { measures of pollution in each } \\
\text { trimester, gestational age, birth } \\
\text { weight, demographic controls, and } \\
\text { zip code/month fixed effects. OLS } \\
\text { models which include large } \\
\text { numbers of covariates, are } \\
\text { estimated for fetal death and low- } \\
\text { birth-weight outcomes. }\end{array}$ & $\begin{array}{l}\text { California EPA monitor data is } \\
\text { used to create weekly ZIP code } \\
\text { averages of ambient pollution } \\
\text { levels which are merged with } \\
\text { weather data from the National } \\
\text { Climatic Data Center, and health } \\
\text { data on births from pregnancies } \\
\text { that reach } 26 \text { weeks gestation from } \\
\text { the California Birth Cohort files } \\
\text { for } 1989-2000 \text {. In total, } 4,593,001 \\
\text { children are in the sample. Each } \\
\text { week of life is treated as a separate } \\
\text { observation yielding 250 million } \\
\text { observations for analysis. }\end{array}$ & $\begin{array}{l}\text { A } 1 \text { unit reduction in CO leads to } \\
2.89 \text { fewer deaths per } 1000 \text { live } \\
\text { births, leading to } 991 \text { fewer infant } \\
\text { deaths in CA attributable to the } \\
\text { drop in CO over the 1990s. Results } \\
\text { are robust in regional and age- } \\
\text { specific subsamples, as well as to } \\
\text { the omission of prenatal exposure } \\
\text { measures, and broader temporal } \\
\text { baskets. Leads and lags analyses } \\
\text { also suggest harvesting is not } \\
\text { significant. Authors do not find } \\
\text { compelling evidence of pre-natal } \\
\text { exposure effects. }\end{array}$ \\
\hline
\end{tabular}


Table 2: Studies of air pollution, fetal health, and infant mortality - Cont'd

\begin{tabular}{|c|c|c|c|}
\hline $\begin{array}{c}\text { Paper / Country / } \\
\text { Source of } \\
\text { Variation }\end{array}$ & Methods & Data/Size & Outcomes \\
\hline $\begin{array}{l}\begin{array}{l}\text { Currie et al. } \\
(2009 b)\end{array} \\
\text { United States } \\
\text { Changes in } \\
\text { pollution levels are } \\
\text { relied upon for } \\
\text { identification }\end{array}$ & $\begin{array}{l}\text { OLS estimations of average } \\
\text { exposure to the three pollutants of } \\
\text { interest during the } 3 \text { trimesters of } \\
\text { pregnancy are made controlling for } \\
\text { weather, mother's characteristics } \\
\text { (including whether and how much } \\
\text { the mother smoked), and child } \\
\text { gender. Similar models are also } \\
\text { estimated with monitor/quarter } \\
\text { fixed effects and mother fixed } \\
\text { effects. An OLS hazard model is } \\
\text { estimated for probability of infant } \\
\text { death in the weeks after birth with } \\
\text { similar controls to the above, plus } \\
\text { birth weight classifications and a } \\
\text { linear spline in weeks since birth. } \\
\text { Analysis is also done separately for } \\
\text { children with smoking mothers. }\end{array}$ & $\begin{array}{l}\text { 1989-2003 New Jersey Department } \\
\text { of Health data on births and deaths } \\
\text { for infants of mothers with } \\
\text { addresses w/in } 10 \mathrm{~km} \text { of a } \\
\text { pollution monitoring station are } \\
\text { merged with observed pollution } \\
\text { levels from the nearest station. } \\
\text { There are } 628,874 \text { observations in } \\
\text { the baseline sample, 283,393 in the } \\
\text { mother fixed-effects sample, and } \\
61,996 \text { children in the smoking } \\
\text { mothers sample. }\end{array}$ & $\begin{array}{l}\text { Negative impacts of 3rd trimester } \\
\text { exposure to CO are found across } \\
\text { specifications (with a one unit } \\
\text { increase in } \mathrm{CO} \text { during the 3rd } \\
\text { trimester leading to an average } \\
\text { birth weight reduction of } 16.65 \mathrm{~g} \text { ). } \\
\text { Results are inconsistent and less } \\
\text { significant for } \mathrm{PM}_{10} \text { and } \mathrm{O}_{3} \text {. The } \\
\text { negative effects of } \mathrm{CO} \text { exposure } \\
\text { continue after birth in the infant } \\
\text { sample with a } 1 \text { ppm decline in } \\
\text { avg. CO levels in the first } 2 \text { weeks } \\
\text { after birth leading to } 0.18 \text { fewer } \\
\text { deaths per } 1000 \text { live births. The } \\
\text { negative impacts of CO are found } \\
\text { even at low levels of ambient CO. }\end{array}$ \\
\hline $\begin{array}{l}\text { Currie and } \\
\text { Schmeider (2009) } \\
\text { United States } \\
\text { Inter-year, within } \\
\text { county variation of } \\
\text { toxic releases is } \\
\text { used for } \\
\text { identification }\end{array}$ & $\begin{array}{l}\text { Effects of toxic chemical releases } \\
\text { (weighted by county area) into the } \\
\text { air are assessed on birth weights, } \\
\text { gestational ages, and infant } \\
\text { mortality. Individual regressions } \\
\text { are run for each outcome variable } \\
\text { against All Toxic releases, } \\
\text { chemicals id'd as affecting } \\
\text { development, and those not, } \\
\text { VOCs, heavy metals, and a number } \\
\text { of individual toxics. A broad set of } \\
\text { county-level controls are employed } \\
\text { including county and year fixed } \\
\text { effects. Similar analyses are also } \\
\text { done comparing fugitive to stack } \\
\text { toxic emissions. }\end{array}$ & $\begin{array}{l}\text { } 5200 \text { county/year observations } \\
\text { are created with Birth and Infant } \\
\text { health data for births in the first } 3 \\
\text { months of the year from the Vital } \\
\text { Statistics Natality data. This is } \\
\text { merged with the prior year's EPA } \\
\text { Toxic Release Inventory data as } \\
\text { well as a rich set of county level } \\
\text { demographic and socioeconomic } \\
\text { controls. The California Office of } \\
\text { Environmental Health Hazard } \\
\text { Assessment's list of known } \\
\text { developmental toxicants is used in } \\
\text { some specifications to ID toxicants } \\
\text { of interest. }\end{array}$ & $\begin{array}{l}\text { Significant, but small-magnitude, } \\
\text { negative effects are found for } \\
\text { releases of a number of toxics on } \\
\text { gestation, birth weights, and } \\
\text { probability of infant death. } \\
\text { Reductions in the emissions of } \\
\text { toluene, lead, and cadmium } \\
\text { account for } \sim 4 \% \text { of the reduction } \\
\text { in infant mortality that occurred in } \\
\text { the late } 1980 \text { s and } 1990 \text { s. Fugitive } \\
\text { emissions have larger effects. } \\
\text { Results are much stronger for } \\
\text { toxics thought to have } \\
\text { developmental effects. }\end{array}$ \\
\hline $\begin{array}{l}\text { Currie and Walker } \\
\text { (2011) } \\
\text { United States } \\
\text { Introduction of } \\
\text { Congestion } \\
\text { Reducing } \\
\text { Automated Toll } \\
\text { Payment Systems }\end{array}$ & $\begin{array}{l}\text { A difference-in-differences } \\
\text { approach is used comparing } \\
\text { changes in birth outcomes (low- } \\
\text { birth weight and prematurity) of } \\
\text { mothers living w/in } 2 \text { km of a } \\
\text { converted toll plaza to changes in } \\
\text { birth outcomes of mothers living } \\
\text { between } 2 \text { km and } 10 \text { km of a toll } \\
\text { station and within } 3 \text { km of a major } \\
\text { freeway. Similar pre-trends are } \\
\text { demonstrated between treatment } \\
\text { and control groups. Regressions } \\
\text { control for mother's race, age, and } \\
\text { education level, multiple births, } \\
\text { and child's gender. Plaza, year, and } \\
\text { month fixed effects are also } \\
\text { included. }\end{array}$ & $\begin{array}{l}\text { Location and date of opening of E- } \\
\text { ZPass toll plaza conversions is } \\
\text { linked to Vital Statistics Natality } \\
\text { records for mothers living near toll } \\
\text { plazas in New Jersey and } \\
\text { Pennsylvania for the years of } \\
1994-2003 \text { and } 1997-2002 \\
\text { respectively. The sample consists } \\
\text { of mothers living within } 10 \mathrm{~km} \text { of } \\
98 \text { toll plazas yielding } 30 \mathrm{k} \text { birth } \\
\text { observations before and after } \\
\text { conversion in the treatment group, } \\
\text { and }>150 \mathrm{k} \text { observations before and } \\
\text { after conversion in the control } \\
\text { group. }\end{array}$ & $\begin{array}{l}\text { Significant reduction in } \\
\text { prematurity and low birth weight } \\
\text { births of } 8.6 \% \text { and } 9.3 \% \\
\text { respectively are associated with the } \\
\text { conversion of toll plazas to the EZ- } \\
\text { Pass systems. Authors show no } \\
\text { significant differential shift in } \\
\text { housing prices near converted toll } \\
\text { stations, suggesting that sorting } \\
\text { isn't occurring in the short term. } \\
\text { Results are robust for non- } \\
\text { smokers, smaller "treatment" and } \\
\text { "control" areas, and to mother } \\
\text { fixed effects. Effects are much } \\
\text { stronger among African-American } \\
\text { mothers. }\end{array}$ \\
\hline
\end{tabular}


Table 2: Studies of air pollution, fetal health, and infant mortality - Cont'd

\begin{tabular}{|c|c|c|c|}
\hline $\begin{array}{c}\text { Paper / Country / } \\
\text { Source of } \\
\text { Variation } \\
\end{array}$ & Methods & Data/Size & Outcomes \\
\hline $\begin{array}{l}\text { Foster et al. (2009) } \\
\text { Mexico } \\
\text { Certification of } \\
\text { businesses under } \\
\text { Mexico's Clean } \\
\text { Industry Certificate } \\
\text { program }\end{array}$ & $\begin{array}{l}\text { Estimated air quality and infant } \\
\text { health outcomes are separately } \\
\text { regressed onto a variable that } \\
\text { captures the fraction of firms } \\
\text { within a municipality that have } \\
\text { been certified by a given month. } \\
\text { Municipality and month-year fixed } \\
\text { effects, and both time varying } \\
\text { municipality controls and the } \\
\text { square of a number of time } \\
\text { invariant municipality } \\
\text { characteristics are also included. } \\
\text { There are only } 94 \text { auditors that can } \\
\text { grant certification, and distance to } \\
\text { these auditors is used as an } \\
\text { instrument for certification. }\end{array}$ & $\begin{array}{l}\text { Daily air quality estimates for all } \\
\text { of Mexico are created from } \\
\text { Aerosol Optical Depth (AOD) } \\
\text { measurements in the MODIS } \\
\text { satellite data. AOD estimates are } \\
\text { aggregated to the monthly- } \\
\text { municipality level, and merged } \\
\text { with estimated temperature and } \\
\text { dew-point controls, infant } \\
\text { mortality data, firm and } \\
\text { employment data, and Clean } \\
\text { Industry Certification awards. } \\
\text { 1,706 municipalities are the focus } \\
\text { of the analysis over the period } \\
\text { from 2000-2006, yielding 32k } \\
\text { observations. }\end{array}$ & $\begin{array}{l}\text { Authors estimate that certification } \\
\text { of all firms in a municipality would } \\
\text { lead to a } 3.6 \% \text { improvement in } \\
\text { AOD and a } 16 \% \text { reduction in } \\
\text { respiratory related infant mortality. } \\
\text { These results are combined to } \\
\text { suggest that a } 1 \% \text { increase in AOD } \\
\text { leads to a } 4.4 \% \text { increase in infant } \\
\text { mortality due to respiratory } \\
\text { ailments. }\end{array}$ \\
\hline $\begin{array}{l}\text { Greenstone and } \\
\text { Hanna (2011) } \\
\text { India } \\
\text { Implementation of } \\
\text { pollution control } \\
\text { policies }\end{array}$ & $\begin{array}{l}\text { Pollutant levels (and later infant } \\
\text { mortality rates) are regressed on a } \\
\text { vector of dummies for years when } \\
\text { each policy was in force, city and } \\
\text { year fixed effects, and } \\
\text { consumption and literacy controls. } \\
3 \text { additional specifications are run } \\
\text { to test for whether yearly average } \\
\text { pollution levels (estimated in the } \\
\text { first specification) are affected by } \\
\text { policy implementations. }\end{array}$ & $\begin{array}{l}\text { 1987-2007 air pollution data from } \\
\text { a total of } 140 \text { cities and 1986-2005 } \\
\text { river water monitor data for } 162 \\
\text { rivers from India's Central } \\
\text { Pollution Control Board is merged } \\
\text { with a city-year dataset on } \\
\text { pollution regulations, and city-year } \\
\text { infant mortality and socio- } \\
\text { economic data. }\end{array}$ & $\begin{array}{l}\text { Air pollution regulations reduced } \\
\text { average ambient levels of } \\
\text { particulates (by } 19 \% \text { ), } \mathrm{SO}_{2} \text { (by } \\
69 \% \text { ), and } \mathrm{NO}_{2} \text { (by an insignificant } \\
15 \% \text { ), but led to statistically } \\
\text { insignificant improvements in } \\
\text { infant mortality. The water } \\
\text { pollution regulations investigated } \\
\text { showed no statistically significant } \\
\text { effects on pollution or health. }\end{array}$ \\
\hline $\begin{array}{l}\text { Janke et al. (2009) } \\
\text { United Kingdom } \\
\text { Inter-temporal } \\
\text { pollutant level } \\
\text { variation used for } \\
\text { identification }\end{array}$ & $\begin{array}{l}\text { Various mortality rates are } \\
\text { regressed on annual levels of the } 4 \\
\text { pollutants, a moderate number of } \\
\text { time-varying local authority } \\
\text { covariates, a time trend, region } \\
\text { specific time trends, and a local } \\
\text { authority fixed effect. }\end{array}$ & $\begin{array}{l}\text { Pollution monitor data for 1998- } \\
2005 \text { from a number of sources is } \\
\text { aggregated to annual averages at } \\
\text { "local authority" level, and then } \\
\text { linked to mortality data at the } \\
\text { authority/year level over the same } \\
\text { period. 2300 authority/year } \\
\text { observations are used in the } \\
\text { analysis. }\end{array}$ & $\begin{array}{l}\text { A } 10 \mu \mathrm{g} / \mathrm{m} 3 \text { increase in } \mathrm{PM}_{10} \text { is } \\
\text { associated with an increase in } \\
\text { death rate of } 4 \text { per } 100,000 \text { among } \\
\text { those under age } 15 \text { (on a mean } \\
\text { mortality rate of } 44 \text { per } 100,000 \text { ). } \\
\text { Other pollutants are not found to } \\
\text { have significant impacts on child } \\
\text { mortality. }\end{array}$ \\
\hline $\begin{array}{l}\text { Jayachandran } \\
(2009) \\
\text { Indonesia } \\
1997 \text { wildfires on } \\
\text { the islands of } \\
\text { Sumatra and } \\
\text { Kalimantan }\end{array}$ & $\begin{array}{l}\text { Regress of the natural log of } \\
\text { district/month cohort sizes on } \\
\text { measures of smoke at (the month } \\
\text { of), before (the } 3 \text { months prior to), } \\
\text { and after (the } 3 \text { months subsequent } \\
\text { to) birth as well as birth } \\
\text { month/year and sub-district fixed } \\
\text { effects. Dates of analysis were } \\
\text { chosen to avoid fertility effects the } \\
\text { fires might have had. }\end{array}$ & $\begin{array}{l}2000 \text { Indonesian Census data, with } \\
\text { analysis by birth-month-cohorts for } \\
\text { December } 1996 \text { to May } 1998 \text { for } \\
3,751 \text { Indonesian sub-districts. } \\
\text { There are } ~ 67 \mathrm{k} \text { children in these } \\
\sim 700 \text { cohorts. The median monthly } \\
\text { values of daily air pollution is } \\
\text { proxied by aerosol measures from } \\
\text { the Earth Probe Total Ozone } \\
\text { Mapping Spectrometer mapped } \\
\text { onto sub-districts. }\end{array}$ & $\begin{array}{l}\text { Pollution from fires led to a } 1.2 \% \\
\text { decrease in cohort size among } \\
\text { children in the third trimester of } \\
\text { pregnancy during the } 5 \text { month } \\
\text { period of the fires. This implies } \\
15,600 \text { fetal, infant, and child } \\
\text { deaths are attributable to the fires, } \\
\text { a } 20 \% \text { overall increase in under-3 } \\
\text { mortality. Results are more } \\
\text { pronounced among boys, and } \\
\text { among lower income households. }\end{array}$ \\
\hline
\end{tabular}


Table 2: Studies of air pollution, fetal health, and infant mortality - Cont'd

\begin{tabular}{|c|c|c|c|}
\hline $\begin{array}{c}\text { Paper / Country / } \\
\text { Source of } \\
\text { Variation } \\
\end{array}$ & Methods & Data/Size & Outcomes \\
\hline $\begin{array}{l}\text { Knittel et al. (2011) } \\
\text { United States } \\
\text { Weekly variation } \\
\text { in ambient } \\
\text { pollution } \\
\text { (instrumented) and } \\
\text { infant mortality is } \\
\text { exploited for } \\
\text { identification }\end{array}$ & $\begin{array}{l}\text { Strong links between traffic } \\
\text { congestion and pollution are } \\
\text { demonstrated. The three pollutants } \\
\text { of interest are instrumented using } \\
\text { traffic congestion interactions with } \\
\text { weather conditions. The main } \\
\text { specification is a discrete time } \\
\text { hazard model estimated as a linear } \\
\text { probability model using person- } \\
\text { week observations which controls } \\
\text { for age in weeks with a flexible } \\
\text { spline. Analysis is done separately } \\
\text { for the } 1989-2000 \text { and } 2002-2007 \\
\text { periods in order to assess whether } \\
\text { lower pollution levels have } \\
\text { different health effects. }\end{array}$ & $\begin{array}{l}\text { 1989-2000 and 2002-2007 } \\
\text { ambient air pollutant levels, } \\
\text { weather conditions, and traffic } \\
\text { densities are merged and } \\
\text { aggregated to the zip code-week } \\
\text { level for much of Central and } \\
\text { Southern California. Infants are } \\
\text { assigned to a zip-code and are } \\
\text { tracked weekly through the first } 52 \\
\text { weeks of life, yielding a sample of } \\
\sim 150 \text { million infant/weeks during } \\
\text { the early time period and } ~ 75 \\
\text { million observations in the later } \\
\text { period. }\end{array}$ & $\begin{array}{l}\text { A one unit reduction in } \mathrm{PM}_{10} \text { leads } \\
\text { to } 18 \text { fewer infant deaths per } \\
100,000 \text { live births. There is ittle } \\
\text { evidence of stable impacts from } \\
\text { CO or Ozone. }\end{array}$ \\
\hline $\begin{array}{l}\text { Lüchinger (2010) } \\
\text { Germany } \\
\text { Mandated } \\
\text { installation of } \mathrm{SO}_{2} \\
\text { scrubbers on power } \\
\text { plants }\end{array}$ & $\begin{array}{l}\text { Difference-in-Differences } \\
\text { comparison of the treatment - } \\
\text { installation of a sulfur scrubber on } \\
\text { a power plant - is made across } \\
\text { treatment and control groups made } \\
\text { up of counties which are } \\
\text { downwind and upwind of power } \\
\text { plants. The frequency of days } \\
\text { downwind from a plant in a given } \\
\text { year is used to weight the } \\
\text { "treatment" group. In addition to } \\
\text { wind direction, treatment levels for } \\
\text { a county are determined by } \\
\text { scrubber installation, plant size, } \\
\text { and plant distance from each } \\
\text { county. }\end{array}$ & $\begin{array}{l}\text { 1985-2003 Infant mortality data is } \\
\text { linked to annual monitor-level } \\
\text { mean } \mathrm{SO}_{2} \text { levels and aggregated to } \\
\text { the county level. Power plant } \\
\text { characteristics and scrubber } \\
\text { installation data is available for all } \\
303 \text { fossil fuel plants with capacity } \\
>100 \text { megawatts during the time } \\
\text { period of interest, and monitor } \\
\text { collected wind data is linked to } \\
\text { each plant. 7500 county-year } \\
\text { observations are used for the main } \\
\text { analysis. }\end{array}$ & $\begin{array}{l}\text { Instrumenting for pollution } \\
\text { changes leads to higher estimates } \\
\text { of the effects of } \mathrm{SO}_{2} \text { on infant } \\
\text { mortality than OLS. The author } \\
\text { finds an elasticity of } 0.08-0.13 \text {, } \\
\text { which suggests that the reduction } \\
\text { of } \mathrm{SO}_{2} \text { observed over the study } \\
\text { period has led to } 895-1528 \text { fewer } \\
\text { infant deaths annually in } \\
\text { Germany.1/3 of the infant } \\
\text { mortality effects of higher } \mathrm{SO}_{2} \\
\text { exposure are realized in the first } \\
\text { day after birth, and } 50-80 \% \text { of the } \\
\text { effects during the first month } \\
\text { outside the womb. }\end{array}$ \\
\hline $\begin{array}{l}\text { Sanders and } \\
\text { Stoecker (2011) } \\
\text { United States } \\
1970 \text { Clean Air Act } \\
\text { Amendments } \\
\text { (CAAAs) }\end{array}$ & $\begin{array}{l}\text { Regression discontinuity at the } \\
\text { time of CAAAs implementation is } \\
\text { implemented via a County-level, } \\
\text { first difference model with state } \\
\text { fixed effects, which is estimated } \\
\text { with the change in pollution from } \\
1970 \text { to } 1972 \text { instrumented by } \\
\text { county estimated nonattainment } \\
\text { status. The outcome examined is } \\
\text { the ratio of male to female live } \\
\text { births; male fetuses are more } \\
\text { susceptible to in utero insults. Thus } \\
\text { increased shares of male live births } \\
\text { suggest fewer fetal deaths. A large } \\
\text { number of county-level covariates } \\
\text { are included as controls, including } \\
\text { TSP level in } 1970 .\end{array}$ & $\begin{array}{l}\text { Birth data from the National } \\
\text { Center for Health Statistics Vital } \\
\text { Statistics Micro-data is merged } \\
\text { with EPA measures of ambient } \\
\text { TSPs and aggregated to the } \\
\text { county-year level. This yields } 281 \\
\text { counties with full desired data, } \\
\text { representing } 50 \% \text { of live births. } \\
\text { First difference is calculated on } \\
\text { changes from } 1970 \text { to } 1972 \text {. }\end{array}$ & $\begin{array}{l}\text { Children are more sensitive to } \\
\text { exposure to TSPs in utero than post } \\
\text { birth. Overall it is estimated that a } \\
1 \text { unit increase in annual average } \\
\text { TSP ambient pollution leads to a } \\
0.088 \text { point change in the } \\
\text { probability of a birth being male. } \\
\text { This suggests that the CAAAs lead } \\
\text { to a } 3.1 \% \text { change in probability of } \\
\text { a male birth, and an estimated } \\
21,000 \text { to } 134,000 \text { avoided fetal } \\
\text { deaths in affected counties ( which } \\
\text { is } 2 \text { to } 13 \% \text { of total births). }\end{array}$ \\
\hline
\end{tabular}


Table 2: Studies of air pollution, fetal health, and infant mortality - Cont'd

\begin{tabular}{|c|c|c|c|}
\hline $\begin{array}{c}\text { Paper / Country / } \\
\text { Source of } \\
\text { Variation } \\
\end{array}$ & Methods & Data/Size & Outcomes \\
\hline $\begin{array}{l}\text { Sneeringer (2009) } \\
\text { United States } \\
\text { Identification arises } \\
\text { from spatial } \\
\text { variation in } \\
\text { livestock } \\
\text { operations due to } \\
\text { farm consolidations }\end{array}$ & $\begin{array}{l}\text { Unit counts of livestock are used to } \\
\text { proxy for pollution from livestock } \\
\text { farming. An OLS regression run } \\
\text { for health outcomes on \# of } \\
\text { livestock in a county and a large } \\
\text { number of time-varying county } \\
\text { covariates capturing: } \\
\text { demographics, population and } \\
\text { housing characteristics, weather } \\
\text { controls, industrial concentrations, } \\
\text { Clean Water Act permits, and other } \\
\text { attributes. Year, county, and state } \\
\text { fixed effects are also included in } \\
\text { the model. }\end{array}$ & $\begin{array}{l}\text { Livestock-by-county information is } \\
\text { taken from a proprietary source } \\
\text { based on NRC data from the 1982, } \\
\text { 1987, 1992, and } 1997 \text { Agricultural } \\
\text { Censuses, and merged with } \\
\text { Restricted-use birth and death } \\
\text { records from the National Center } \\
\text { for Health Statistics for 1980-1999. } \\
\text { Additional county-level controls } \\
\text { are taken from a variety of other } \\
\text { sources. Ultimately, 9,223 county- } \\
\text { 5-year-period observations are } \\
\text { used, based on } 75 \mathrm{M} \text { total births. }\end{array}$ & $\begin{array}{l}123 \text { more deaths of infants }<1 \text { year } \\
\text { old and } 100 \text { more deaths of infants } \\
<28 \text { days old per } 100,000 \text { live } \\
\text { births result from an increase of } \\
100,000 \text { animal units in a county. } \\
\text { The average annual unit increase } \\
\text { from } 1982 \text { to } 1997 \text { (for counties } \\
\text { with increases) was 35\%, } \\
\text { suggesting a } 2.8 \% \text { increase in } \\
\text { infant mortality in these counties, } \\
\text { or a total of 3,500 additional infant } \\
\text { deaths in the U.S. over the time } \\
\text { period. Effects are connected to air } \\
\text { rather than water pollution through } \\
\text { a number of findings. }\end{array}$ \\
\hline
\end{tabular}

Table 3 - Panel A: Studies of air pollution and child health

\begin{tabular}{|c|c|c|c|}
\hline $\begin{array}{c}\text { Paper / Country / } \\
\text { Source of } \\
\text { Variation } \\
\end{array}$ & Methods & Data/Size & Outcomes \\
\hline $\begin{array}{l}\text { Beatty and } \\
\text { Shimshack (2011) } \\
\text { United States } \\
\text { School bus } \\
\text { emissions } \\
\text { reductions }\end{array}$ & $\begin{array}{l}\text { Authors first use a } 2 \text { period D-in-D } \\
\text { specification where changes in } \\
\text { health outcomes (from } 2002 \text { to } \\
\text { 2006) in districts that had } \\
\text { significantly retrofitted their bus } \\
\text { fleets by } 2006 \text { are compared to } \\
\text { health outcomes in districts that } \\
\text { hadn't yet begun retrofits. The } \\
\text { second specification is a month by } \\
\text { month D-in-D (with month, year, } \\
\text { and district dummies) comparing } \\
\text { before and after periods (variously } \\
\text { defined by a school reaching a } \\
\text { number of different retrofit } \\
\text { thresholds). All specifications } \\
\text { control for a small number of } \\
\text { district and weather covariates. } \\
\text { Economic and weather controls as } \\
\text { well as county and state/year fixed } \\
\text { effects are also included in the } \\
\text { regressions. }\end{array}$ & $\begin{array}{l}\text { Washington State data on bus } \\
\text { retrofit program adoption (state } \\
\text { funded) from } 53 \text { school districts } \\
\text { (with } \sim 4000 \text { total buses) is linked } \\
\text { to hospital discharge data for } 1996 \text { - } \\
2006 \text { and Census demographic } \\
\text { data. Then everything is } \\
\text { aggregated to the School District- } \\
\text { month level with a total of } \sim 5830 \\
\text { observations for analysis. }\end{array}$ & $\begin{array}{l}\text { Preferred estimates demonstrate } \\
\text { that school districts that adopt } \\
\text { emissions reducing retrofits on } \\
\text { their school bus fleets experience } \\
23 \% \text { fewer bronchitis and asthma } \\
\text { cases, and } 37 \% \text { fewer children's } \\
\text { pneumonia cases per month. } \\
\text { Results are attributed to within bus } \\
\text { exposure to bus emissions. }\end{array}$ \\
\hline $\begin{array}{l}\text { Lavaine and } \\
\text { Neidell (2013) } \\
\text { France } \\
\text { Temporary } \\
\text { shutdown (due to } \\
\text { strikes) of oil } \\
\text { refineries }\end{array}$ & $\begin{array}{l}\text { Pollution exposure of admitted } \\
\text { patients is estimated, and then } \\
\text { census tract respiratory hospital } \\
\text { admissions are regressed on this } \\
\text { exposure measure weather controls } \\
\text { and tract, month, and year fixed } \\
\text { effects. Since exposure is } \\
\text { endogenous, it is instrumented } \\
\text { using an indicator for whether the } \\
\text { census tract is close to a refining } \\
\text { facility affected by strikes, and } \\
\text { whether the month is October } 2010 \\
\text { (when the strikes were in force). }\end{array}$ & $\begin{array}{l}\text { Respiratory hospitalizations data } \\
\text { from the French National Hospital } \\
\text { Discharge Database is merged with } \\
\text { pollution, weather, and } \\
\text { socioeconomic data. After } \\
\text { dropping tracts and refineries for } \\
\text { which key pieces of data are } \\
\text { missing, 3,100 French census tracts } \\
\text { are left with data for } 2007-2010 \text {. }\end{array}$ & $\begin{array}{l}\text { Authors find that } \mathrm{SO}_{2} \text { levels well } \\
\text { below current quality standards } \\
\text { lead to significant health impacts, } \\
\text { especially among the at-risk } \\
\text { populations of the elderly and the } \\
\text { young. A one month, } 1 \mu \mathrm{g} / \mathrm{m} 3 \\
\text { decrease in } \mathrm{SO}_{2} \text { concentrations } \\
\text { leads to a } 5 \text { gram increase in avg. } \\
\text { birthweights and a } 0.18 \text { day } \\
\text { increase in gestational age. Impacts } \\
\text { appear to be strongest during the } \\
\text { third trimester. }\end{array}$ \\
\hline
\end{tabular}


Table 3 - Panel A: Studies of air pollution and child health - Cont'd

\begin{tabular}{|c|c|c|c|}
\hline $\begin{array}{c}\text { Paper / Country / } \\
\text { Source of } \\
\text { Variation }\end{array}$ & Methods & Data/Size & Outcomes \\
\hline $\begin{array}{l}\text { Currie et al. } \\
\text { (2013b) } \\
\text { United States } \\
\text { Differential in } \\
\text { utero exposure to } \\
\text { drinking water } \\
\text { contamination } \\
\text { violations between } \\
\text { siblings is used for } \\
\text { identification }\end{array}$ & $\begin{array}{l}\text { Uses exogenous location } \\
\text { assignments of army personnel and } \\
\text { the uniform nature of } \\
\text { housing/services across Army } \\
\text { bases to identify contemporaneous } \\
\text { effects of } 5 \text { pollutants on child } \\
\text { hospitalizations. A linear } \\
\text { probability model is estimated for } \\
\text { whether a child was hospitalized in } \\
\text { a given year based on levels of the } \\
5 \text { pollutants, weather controls, } \\
\text { child characteristics, base fixed } \\
\text { effects and base/year } \\
\text { characteristics, and father's } \\
\text { rank/occupation/year fixed effects. }\end{array}$ & $\begin{array}{l}\text { Annual Individual level data on all } \\
\text { enlisted men stationed in the } \\
\text { Continental U.S. from 1988-1998, } \\
\text { and hospitalization data (including } \\
\text { condition) for all their wives and } \\
\text { children, is linked (via Kriging } \\
\text { methods) to annual EPA and } \\
\text { weather data. This provides } \\
159,275 \text { annual observations of } \\
\text { children } 0-5 \text { years old and 44,663 } \\
\text { of children under age } 1 .\end{array}$ & $\begin{array}{l}\text { No impacts are found for children } \\
\text { age } 0 \text {-1 year old. For children } 2-5 \\
\text { years old, increased probabilities } \\
\text { of respiratory hospitalization are } \\
\text { associated with higher levels of } \mathrm{O}_{3} \\
\text { in all samples, and } \mathrm{CO} \text { also } \\
\text { contributes significantly for } \\
\text { children of families that didn't } \\
\text { move in a given year. A one SD } \\
\text { increase in } \mathrm{O}_{3} \text { levels leads to an 8- } \\
25 \% \text { increase in the likelihood of } \\
\text { respiratory hospitalization among } \\
\text { children ages } 2-5 \text {, implying an } \\
\text { elasticity of } 0.5 \text { to } 1.5 \text {. }\end{array}$ \\
\hline $\begin{array}{l}\text { Neidell (2009) } \\
\text { United States } \\
\text { Smog Alerts }\end{array}$ & $\begin{array}{l}\text { Assesses whether behaviors } \\
\text { change when an Ozone Alert } \\
\text { occurs using a regression } \\
\text { discontinuity approach, regressing } \\
\text { log of attendance at the outdoor } \\
\text { attractions on an indicator for a } \\
\text { local Ozone, a function in forecast } \\
\text { ozone levels, controls for weather } \\
\text { and other air pollutants, and } \\
\text { indicators for holidays, summer } \\
\text { schedule, and day of week. A } \\
\text { similar regression is run with the } \\
\text { outcome variable of asthma } \\
\text { hospitalizations (by age), and also } \\
\text { includes interactions of lagged } \\
\text { ozone forecasts and levels, as well } \\
\text { as indicators for Ozone alerts. }\end{array}$ & $\begin{array}{l}\text { Daily attendance data for two } \\
\text { outdoor attractions (the LA Zoo \& } \\
\text { Griffith Observatory) for 1989- } \\
1997 \text { is merged with hospital } \\
\text { discharge data, weather data, and } \\
\text { data on both predicted and actual } \\
\text { ozone levels in } 10 \text { Air Monitoring } \\
\text { Zones in the Los Angeles area. }\end{array}$ & $\begin{array}{l}\text { People respond to public } \\
\text { information about pollution by } \\
\text { spending less time outside. } \\
\text { Ignoring avoidance behavior } \\
\text { understates the negative impacts of } \\
\text { pollutants (specifically Ozone) on } \\
\text { health outcomes of the young and } \\
\text { elderly. A } 0.01 \text { ppm increase in } \\
\text { the 5-day Ozone levels increases } \\
\text { child hospital admissions by } \\
\text { 1.09\%, but when smog alerts are } \\
\text { controlled for, this jumps to a } \\
2.88 \% \text { increase in such child } \\
\text { hospital admissions. }\end{array}$ \\
\hline $\begin{array}{l}\text { Neidell (2004) } \\
\text { United States } \\
\text { Intra-zip code } \\
\text { variation in } \\
\text { seasonal air } \\
\text { pollution levels is } \\
\text { used for } \\
\text { identification }\end{array}$ & $\begin{array}{l}\text { Zip code-month ER admissions for } \\
\text { asthma are regressed on } \\
\text { contemporaneous measures of four } \\
\text { air pollutants, the number of air } \\
\text { quality episodes (a proxy for } \\
\text { avoidance behavior), a number of } \\
\text { covariates (including weather), and } \\
\text { dummy variables for each zip } \\
\text { code- year and year-month. Model } \\
\text { is estimated separately for each of } \\
5 \text { age groups in the } 1-18 \text { age range. }\end{array}$ & $\begin{array}{l}\text { Zip code level data for California } \\
\text { is aggregated for hospital } \\
\text { discharges due to asthma for ages } \\
\text { 1-18, weather monitors, and air } \\
\text { pollution monitors for the period of } \\
\text { 1992-1998. Demographic, home } \\
\text { values, and Ozone alerts data is } \\
\text { also used. This provides 50,000 } \\
\text { zip code-month observations for } \\
\text { analysis. }\end{array}$ & $\begin{array}{l}\text { CO has e a significant effect on } \\
\text { asthma for kids 1-18. If } 1998 \\
\text { levels of CO were at their } 1992 \\
\text { levels, 5-14\% more hospital } \\
\text { admissions due to asthma would } \\
\text { have been expected. Avoidance } \\
\text { behavior significantly reduces the } \\
\text { negative effects of air pollution. } \\
\text { Negative air pollution effects are } \\
\text { larger among children of lower } \\
\text { socio-economic status. }\end{array}$ \\
\hline $\begin{array}{l}\text { Ransom and Pope } \\
(1995) \\
\text { United States } \\
\text { Temporary closure } \\
\text { of steel mill in } \\
\text { Utah }\end{array}$ & $\begin{array}{l}\text { A difference-in-differences } \\
\text { approach comparing logged health } \\
\text { outcomes in a valley with a } \\
\text { (intermittently shut down) steel } \\
\text { mill to logged health outcomes in } \\
\text { a nearby valley (with no mill) is } \\
\text { used with negative binomial } \\
\text { regression models. Regressions } \\
\text { include seasonal controls, but few } \\
\text { other covariates. }\end{array}$ & $\begin{array}{l}\text { Data on local counts of daily } \\
\text { deaths and hospital admissions } \\
\text { (including reason for admission) } \\
\text { for individuals living in two } \\
\text { distinct valleys in Utah (the Utah } \\
\text { and Cache Valleys) is linked to } \\
\text { data on the temporary 13-month } \\
\text { closure of a large steel mill (due to } \\
\text { a labor dispute) in } 1986 \text { and } 1987 .\end{array}$ & $\begin{array}{l}\text { Hospital admissions for respiratory } \\
\text { ailments increase significantly } \\
\text { when the mill was open (relative to } \\
\text { the control). Admissions due to } \\
\text { bronchitis and asthma nearly } \\
\text { doubled among preschoolers in the } \\
\text { treatment valley when the mill was } \\
\text { open vs. closed (compared to } \\
\text { almost no change in the control } \\
\text { valley), and resulted in an } 60 \\
\text { additional hospital admissions per } \\
\text { year in this age group. }\end{array}$ \\
\hline
\end{tabular}


Table 3 - Panel A: Studies of air pollution and child health - Cont'd

\begin{tabular}{|c|c|c|c|}
\hline $\begin{array}{c}\text { Paper / Country / } \\
\text { Source of } \\
\text { Variation }\end{array}$ & Methods & Data/Size & Outcomes \\
\hline $\begin{array}{l}\text { Reyes (2012) } \\
\text { United States } \\
\text { Differential rates of } \\
\text { declines in leaded } \\
\text { fuel usage between } \\
\text { states are used for } \\
\text { identification }\end{array}$ & $\begin{array}{l}\text { The relationship between blood } \\
\text { lead and effective grams of lead in } \\
\text { purchased gasoline is determined } \\
\text { via a simple OLS regression using } \\
\text { the NHANES II data (and a } \\
\text { number of individual controls), and } \\
\text { the resulting estimates are used to } \\
\text { predict (by state, age, year of birth, } \\
\text { and a number of other individual } \\
\text { characteristics) blood lead levels at } \\
\text { age } 0 \text {-3 for those surveyed in the } \\
\text { NLSY. Childhood and young adult } \\
\text { outcomes are then regressed (using } \\
\text { OLS, probit, ordered probit, or } \\
\text { censored tobit depending on the } \\
\text { outcome) on this estimated value } \\
\text { of blood lead and a vector of } \\
\text { individual demographics, as well } \\
\text { as dummies for mother's age and } \\
\text { birth cohorts. }\end{array}$ & $\begin{array}{l}\text { Individual outcome data on } \sim 10 \mathrm{k} \\
\text { young adults from the NLSY } 79 \\
\text { and NLSY } 97 \text { surveys is linked to } \\
\text { state-month estimates of effective } \\
\text { grams of lead per gallon of } \\
\text { purchased gasoline (for the time } \\
\text { period when the child was } 0-3 \\
\text { years of age), and census data. } \\
\text { Additionally, 1976-1980 blood } \\
\text { level data from } 2,322 \text { children } \\
\text { under age } 6 \text { from the NHANES II } \\
\text { is linked to the grams of lead per } \\
\text { gallon measure by state. }\end{array}$ & $\begin{array}{l}\text { Large negative impacts of early } \\
\text { childhood lead exposure are found } \\
\text { on outcomes including childhood } \\
\text { behavioral problems, teenage } \\
\text { aggression and pregnancy, and } \\
\text { young adult criminal behaviors. } \\
\text { The elasticities between these } \\
\text { behaviors and lead exposure range } \\
\text { from } 0.2 \text { to } 1.0 \text {. }\end{array}$ \\
\hline $\begin{array}{l}\text { Schlenker and } \\
\text { Walker (2011) } \\
\text { United States } \\
\text { Airport delays at } \\
\text { East Coast hubs }\end{array}$ & $\begin{array}{l}\text { Examine effect of pollution from } \\
\text { airports on ER visits and } \\
\text { hospitalizations for respiratory and } \\
\text { heart ailments. Instrument for } \\
\text { pollution levels in zip codes near } \\
\text { airports with delays at East Coast } \\
\text { hub airports (which lead to delays } \\
\text { and increased taxiing, and thus } \\
\text { increased pollution at the } \\
\text { California airports that are the } \\
\text { focus of this study). Additionally, } \\
\text { wind variation (interacted with } \\
\text { East Coast taxiing congestion) is } \\
\text { used as an additional instrument } \\
\text { for pollution in zip codes near } \\
\text { major California airports. }\end{array}$ & $\begin{array}{l}\text { Daily data on air pollution levels, } \\
\text { weather, hospital admissions, and } \\
\text { ER visits for zip codes surrounding } \\
\text { California's } 12 \text { largest airports is } \\
\text { linked to Department of } \\
\text { Transportation data on taxiing time } \\
\text { at these airports and } 3 \text { major } \\
\text { eastern hubs. Zip code direction } \\
\text { from nearest airport and wind } \\
\text { direction data is also included. } \\
\text { Main sample is } 180 \mathrm{k} \text { day-zip } \\
\text { code observations from } 2005-2007 .\end{array}$ & $\begin{array}{l}\text { Increased taxiing leads to } \\
\text { significant increases in ground- } \\
\text { level air pollution near airports. A } \\
1 \text { SD increase in taxiing time at } \\
\text { LAX increases CO levels near the } \\
\text { airport by } 0.32 \text { SDs and } 0.23 \text { SDs } \\
10 \text { km from the airport. A } 1 \text { ppb } \\
\text { increase in CO leads to } 0.8 \\
\text { additional daily hospital visits per } \\
10 \text { million children under } 5 \text { year } \\
\text { due to asthma and } 5.5 \text { additional } \\
\text { hospital visits among due to all } \\
\text { respiratory ailments. The elderly } \\
\text { and the young to be more sensitive, } \\
\text { but impacts of CO are found across } \\
\text { all ages. Significant effects are not } \\
\text { found for } \mathrm{NO}_{2} \text { or } \mathrm{O}_{3} \text {. }\end{array}$ \\
\hline $\begin{array}{l}\text { Yu (2011) } \\
\text { China } \\
\text { Intervention } \\
\text { assignment }\end{array}$ & $\begin{array}{l}\text { A number of D-in-D models are } \\
\text { estimated. Due to apparent non- } \\
\text { random sample selection, assigned } \\
\text { treatment and control groups are } \\
\text { not the preferred specification. } \\
\text { Author employs propensity score } \\
\text { matching following Abadie et al. } \\
\text { (2001) to better construct matched } \\
\text { treatment and control groups. The } \\
\text { matching variables are validated } \\
\text { following Imbens (2010) and } \\
\text { checked using false treatments. }\end{array}$ & $\begin{array}{l}1050 \text { children }<5 \text { years of age in } \\
\text { rural Chinese households were } \\
\text { examined } 6 \text { times before and } 8 \\
\text { times after the intervention, which } \\
\text { was implemented on } 3 \text { groups of } \\
\text { households. The first received } \\
\text { subsidized stoves and a behavioral } \\
\text { intervention, the second, only a } \\
\text { behavioral intervention, and the } \\
\text { third served as a control. }\end{array}$ & $\begin{array}{l}\text { Both interventions were effective } \\
\text { in reducing acute incidence of both } \\
\text { upper (by 9-23\%) and lower (by } 1 \\
\text { to 3\%) respiratory infections } \\
\text { among small children, though the } \\
\text { additional intervention of stove } \\
\text { subsidization was not found to } \\
\text { have significantly better outcomes } \\
\text { among children. }\end{array}$ \\
\hline
\end{tabular}


Table 3 - Panel B: Studies of air pollution and children's schooling and cognition

\begin{tabular}{|c|c|c|c|}
\hline $\begin{array}{c}\text { Paper / Country / } \\
\text { Source of } \\
\text { Variation }\end{array}$ & Methods & Data/Size & Outcomes \\
\hline $\begin{array}{l}\text { Currie et al. } \\
\text { (2009a) } \\
\text { United States } \\
\text { Changes in counts } \\
\text { of binned pollution } \\
\text { levels used for } \\
\text { identification }\end{array}$ & $\begin{array}{l}\text { A triple differences model is } \\
\text { employed, holding school, year, } \\
\text { and 6-week attendance period } \\
\text { characteristics constant to examine } \\
\text { the effects of shifts in the \# of days } \\
\text { in } 5 \text { levels bins on attendance for } \\
\text { each of the } 4 \text { pollutants of interest. } \\
\text { School demographic \& age } \\
\text { characteristics, as well as } \\
\text { precipitation and temperatures are } \\
\text { controlled for. }\end{array}$ & $\begin{array}{l}\text { 1996-2001 Administrative data } \\
\text { from schools within } 10 \text { miles of a } \\
\text { pollution monitoring station from } \\
\text { the } 39 \text { largest school districts in } \\
\text { Texas is merged with ambient } \\
\text { pollution data from these monitors. } \\
\text { The attendance data from the } 1,512 \\
\text { schools is in } 6 \text { week blocks at the } \\
\text { school level, so hourly pollution } \\
\text { data is aggregated to that } \\
\text { granularity, resulting in }>12 \text { million } \\
\text { student-attendance period-year } \\
\text { observations. }\end{array}$ & $\begin{array}{l}\text { CO levels below the current EPA } \\
\text { Air Quality Standards lead to } \\
\text { increases in school absences. } \\
\text { Specifically, the reduction in high- } \\
\text { CO days during the period of the } \\
\text { study led to a } 0.8 \text { percentage point } \\
\text { (on a } 3.58 \% \text { base) reduction in } \\
\text { absences, with large impacts for } \\
\text { vulnerable populations such as } \\
\text { asthmatics. No statistically } \\
\text { significant relationship is found } \\
\text { between more days with high } \mathrm{PM}_{10} \\
\text { or Ozone and increased absences. }\end{array}$ \\
\hline $\begin{array}{l}\text { Lavy et al. (2012) } \\
\text { Israel } \\
\text { Natural variation of } \\
\text { pollution on test } \\
\text { days is used for } \\
\text { identification }\end{array}$ & $\begin{array}{l}\text { Fixed effects regressions are run of } \\
\text { student test scores on } \\
\text { contemporaneous weather and } \\
\text { pollution variables, with results } \\
\text { presented for student, school, and } \\
\text { city level fixed effects models. } \\
\text { Controls for student and parental } \\
\text { characteristics and month and test } \\
\text { level fixed effects are also } \\
\text { included. }\end{array}$ & $\begin{array}{l}\sim 300 \mathrm{k} \text { (for } \mathrm{PM}_{2.5} \text { ) and } \sim 150 \mathrm{k} \text { (for } \\
\text { other pollutants) test scores from } \\
\text { the years of } 2000-2002 \text { are } \\
\text { matched to contemporaneous } \\
\text { pollution and weather conditions. } \\
\text { Test scores are from the Bagrut (A } \\
\text { high school graduation } \\
\text { requirement for academic track). } \\
\text { Pollution data is from } 139 \text { stations } \\
\text { across Israel, assigned to students } \\
\text { based on city of test and monitor } \\
\text { locations w/in } 2.5 \text { km of the city } \\
\text { limits. }\end{array}$ & $\begin{array}{l}\text { Higher levels of both } \mathrm{PM}_{2.5} \text { and } \\
\text { CO are associated with lower } \\
\text { scores. A PM } \mathrm{PM}_{2.5} \text { Air Quality Index } \\
(\mathrm{AQI})>100 \text { associated with } \sim 2.5 \\
\text { points less (out of } 100 \text { ) and a CO } \\
\text { AQI }>100 \text { associated with } ~ 9.5 \\
\text { fewer points scored. This effect is } \\
\text { homogeneous for CO, but more } \\
\text { intense among groups with higher } \\
\text { rates of asthma for } \mathrm{PM}_{2.5} \text {. }\end{array}$ \\
\hline $\begin{array}{l}\text { Reyes (2011) } \\
\text { United States } \\
\text { Identification } \\
\text { comes from within- } \\
\text { school, inter- } \\
\text { temporal variation } \\
\text { of blood lead levels }\end{array}$ & $\begin{array}{l}\text { Cohort average test scores are } \\
\text { regressed on a measure of blood } \\
\text { lead (either levels or indicator of \# } \\
\text { of children over certain } \\
\text { thresholds), a broad set of } \\
\text { community, district, and school } \\
\text { specific controls, and year fixed } \\
\text { effects. An OLS regression } \\
\text { weighted by cohort size is the main } \\
\text { estimation method. }\end{array}$ & $\begin{array}{l}\text { A panel of school-level cohort-year } \\
\text { data on 3rd and 4th graders from } \\
>1,000 \text { public schools in Mass. } \\
\text { between 2000-2009 is created } \\
\text { through the aggregation of } \\
\text { individual-level standardized test } \\
\text { scores and blood level } \\
\text { measurements. Additional school } \\
\text { and community level controls are } \\
\text { gathered from state and federal } \\
\text { data sources. } 18 \mathrm{k} \text { cohort-year } \\
\text { observations are used in the } \\
\text { analysis. }\end{array}$ & $\begin{array}{l}\text { Blood lead level data from the } \\
\text { 1990s coupled with test } \\
\text { performance data from the 2000s is } \\
\text { used to demonstrate the strong } \\
\text { cross-sectional link between } \\
\text { childhood blood lead levels and } \\
\text { test scores in elementary schools. } \\
\text { However, such links are not robust } \\
\text { to the inclusion of significant } \\
\text { covariates. The lead reduction } \\
\text { levels observed over the time } \\
\text { period reduced the share of } \\
\text { children scoring unsatisfactory on } \\
\text { standardized tests by 1-2 } \\
\text { percentage points. }\end{array}$ \\
\hline $\begin{array}{l}\text { Zweig et al. (2009) } \\
\text { United States } \\
\text { Identification } \\
\text { comes from inter- } \\
\text { temporal variation } \\
\text { of pollution and } \\
\text { test scores within } \\
\text { cities }\end{array}$ & $\begin{array}{l}\text { Average class test scores by } \\
\text { subject are regressed on a number } \\
\text { of measures of contemporaneous } \\
\text { pollution, controls for time variant } \\
\text { average student, family, and } \\
\text { school characteristics, city } \\
\text { unemployment levels, and school } \\
\text { fixed effects. A specification with } \\
\text { year fixed effects is also estimated. }\end{array}$ & $\begin{array}{l}\text { Individual, survey data from three } \\
\text { cohorts of students from the } \\
\text { Children's Health Study (CHS) in } \\
88 \text { Southern Californian schools is } \\
\text { aggregated to the class-school-year } \\
\text { level and merged with publicly } \\
\text { available data on schools, } \\
\text { communities, and test scores. } \\
\text { These } 216 \text { observations are linked } \\
\text { to contemporaneous yearly average } \\
\text { measures of air pollution for } \\
\text { monitors placed by CHS. }\end{array}$ & $\begin{array}{l}\text { A } 10 \% \text { decrease in the ambient } \\
\text { levels of } \mathrm{PM}_{10}, \mathrm{PM}_{2.5} \text {, and } \mathrm{NO}_{2} \text { led } \\
\text { to increased scores on standardized } \\
\text { math tests of } 0.15 \%, 0.34 \% \text {, and } \\
0.18 \% \text { respectively. Only } \mathrm{PM}_{2.5} \\
\text { levels are found to contribute } \\
\text { significantly to reading scores, } \\
\text { with a } 10 \% \text { reduction in the annual } \\
\text { average } \mathrm{PM}_{2.5} \text { level associated with } \\
\text { a } 0.21 \% \text { increase in reading scores. } \\
\text { Annual Ozone levels are not found } \\
\text { to contribute significantly to } \\
\text { reading or math scores. }\end{array}$ \\
\hline
\end{tabular}


Table 4: Studies of water pollution

\begin{tabular}{|c|c|c|c|}
\hline $\begin{array}{c}\text { Paper / Country / } \\
\text { Source of } \\
\text { Variation }\end{array}$ & Methods & Data/Size & Outcomes \\
\hline $\begin{array}{l}\text { Brainerd and } \\
\text { Menon (2012) } \\
\text { India } \\
\text { Temporal and } \\
\text { Regional Variation } \\
\text { in fertilizer use, } \\
\text { leading to } \\
\text { differential } \\
\text { exposure (via } \\
\text { water) to young } \\
\text { children of } \\
\text { different ages and } \\
\text { regions }\end{array}$ & $\begin{array}{l}\text { Statewide measures of waterborne } \\
\text { agricultural pollutants in the month } \\
\text { of conception are regressed on } \\
\text { health outcomes. Levels of non- } \\
\text { agricultural water pollutants, a } \\
\text { wide range of mother, father, } \\
\text { household, and state of residence } \\
\text { characteristics are controlled for. } \\
\text { Interacted regional and month/year } \\
\text { of conception fixed effects are also } \\
\text { included. Preferred specification } \\
\text { utilizes month/region planting } \\
\text { seasons as instrumental variables } \\
\text { for the presence of agricultural } \\
\text { pollutants. }\end{array}$ & $\begin{array}{l}\text { Estimated State/Month-level water } \\
\text { quality date for 1978-2005 is } \\
\text { merged with } 3 \text { rounds of the Indian } \\
\text { National Family Health Survey } \\
\text { (1992, 1998, \& 2005), yielding in } \\
\text { utero pollutant exposure estimates } \\
\text { and health outcomes (as well as } \\
\text { demographic controls) for } \sim 400 \mathrm{k} \\
\text { births. }\end{array}$ & $\begin{array}{l}\text { The instrument is validated by } \\
\text { demonstrating that average } \\
\text { fertilizer levels in water are higher } \\
\text { in planting months. A } 10 \% \\
\text { increase in the avg. agro-chemical } \\
\text { levels in the water during the } \\
\text { month of conception is associated } \\
\text { with a } 3.52 \% \text { increase in infant } \\
\text { mortality and a } 6.65 \% \text { increase in } \\
\text { neonatal mortality. A } 10 \% \text { increase } \\
\text { in agro-chemical water pollutants } \\
\text { in the month of conception leads to } \\
\text { a } 0.26 \text { standard deviation reduction } \\
\text { in age-five z scores. }\end{array}$ \\
\hline $\begin{array}{l}\text { Clay et al. (2010) } \\
\text { United States } \\
\text { Cross city variation } \\
\text { from water } \\
\text { chemistry and } \\
\text { utilization of lead } \\
\text { service pipes }\end{array}$ & $\begin{array}{l}\text { An examination of infant mortality } \\
\text { and worker productivity using } \\
\text { OLS regressions on water pH and } \\
\text { interactions of water pH with } \\
\text { service pipe materials. A rich set } \\
\text { of city characteristic (including } \\
\text { water and milk quality and } \\
\text { women's suffrage), regional fixed } \\
\text { effects, and climactic controls are } \\
\text { utilized, and possible selection into } \\
\text { pipe choice is addressed by } \\
\text { repeating the analysis among lead- } \\
\text { pipe-only cities. }\end{array}$ & $\begin{array}{l}\text { City-level mortality, population, } \\
\text { and demographic characteristics } \\
\text { for 1900, 1910, and } 1920 \text { are } \\
\text { merged with service pipe and } \\
\text { water chemistry data by city from } \\
\text { The Manual of American } \\
\text { Waterworks, } 1897 \text { and The Water } \\
\text { Encyclopedia respectively. } \\
\text { Ultimately } 200 \text { cities are in the } \\
\text { data for each of the } 3 \text { years } \\
\text { analyzed. Wage estimates by city } \\
\text { in } 18991904,1909, \& 1914 \text { are } \\
\text { from the Census of Manufacturing. }\end{array}$ & $\begin{array}{l}\text { In } 1900 \text {, an all-lead-service-pipe } \\
\text { city ( } \sim 11 \% \text { of the U.S. population) } \\
\text { could reduce infant mortality by } 12 \\
\text { to } 14 \% \text { with a drinking water pH } \\
\text { reduction from } 6.7 \text { to } 7.5 \text {, (i.e. } \\
\text { moving from the } 25 \text { th percentile to } \\
\text { the } 50 \text { th), } 25 \% \text { of the decline in } \\
\text { infant mortality in these cities from } \\
1900-1920 \text { is attributable to } \\
\text { decreased lead exposure. } \\
\text { Suggestive evidence is shown that } \\
\text { wages were lower in cities with } \\
\text { higher lead exposure and higher } \\
\text { infant mortality. }\end{array}$ \\
\hline $\begin{array}{l}\text { Currie et al. } \\
\text { (2013b) } \\
\text { United States } \\
\text { Differential in } \\
\text { utero exposure to } \\
\text { drinking water } \\
\text { contamination } \\
\text { violations between } \\
\text { siblings is used for } \\
\text { identification }\end{array}$ & $\begin{array}{l}\text { Mother fixed effect model is } \\
\text { estimated comparing sibling birth } \\
\text { outcomes (birth weight \& } \\
\text { prematurity) from the same mother } \\
\text { while controlling for bins of } \\
\text { mother's age, mother's race, } \\
\text { education level, marital status, and } \\
\text { risk factors, as well as child } \\
\text { gender, weather controls, and } \\
\text { year*month of birth fixed effects. } \\
\text { Also estimated are models } \\
\text { analyzing characteristics of } \\
\text { mothers who move in response to } \\
\text { contamination information, and IV } \\
\text { models with instrument } \\
\text { constructed using mother's initial } \\
\text { residence. }\end{array}$ & $\begin{array}{l}\text { 1997-2007 Birth outcomes from } \\
\text { natality records are merged with } \\
\text { records on drinking water } \\
\text { contamination violations, } \\
\text { temperature and precipitation data, } \\
\text { and drinking water service areas } \\
\text { for the same time period. Births } \\
\text { from multi-child families identified } \\
\text { as being part of a water service } \\
\text { area are used, yielding 529,565 } \\
\text { observations. }\end{array}$ & $\begin{array}{l}\text { It is found that the children of less } \\
\text { educated women are much more } \\
\text { susceptible to contamination of } \\
\text { drinking water in utero, with a } \\
14.55 \% \text { increased likelihood of } \\
\text { low birth weight and a } 10.3 \% \\
\text { increased chance of a premature } \\
\text { birth associated with living in a } \\
\text { district with contaminated water } \\
\text { during the pregnancy. }\end{array}$ \\
\hline
\end{tabular}


Table 4: Studies of water pollution - Cont'd

\begin{tabular}{|c|c|c|c|}
\hline $\begin{array}{c}\text { Paper / Country / } \\
\text { Source of } \\
\text { Variation }\end{array}$ & Methods & Data/Size & Outcomes \\
\hline $\begin{array}{l}\text { Troesken (2008) } \\
\text { United States } \\
\text { Differences in lead } \\
\text { pipe usage, age of } \\
\text { pipes and water } \\
\text { chemistry across } \\
\text { municipalities is } \\
\text { used for } \\
\text { identification }\end{array}$ & $\begin{array}{l}\text { Cross sectional regressions of } 1900 \\
\text { infant mortality and still-birth rates } \\
\text { on an indicator for city usage of } \\
\text { lead service pipes as well as a } \\
\text { moderate number of city covariates } \\
\text { including measures of population, } \\
\text { infectious disease environment, } \\
\text { and public health infrastructures. } \\
\text { City observations are weighted by } \\
\text { population. A number of } \\
\text { specifications are assessed to try } \\
\text { and control for correlation between } \\
\text { avoidance of lead pipe usage and a } \\
\text { city's unobserved "health } \\
\text { consciousness". }\end{array}$ & $\begin{array}{l}\text { Lead service pipe usage for } 74 \\
\text { Massachusetts towns in } 1900 \text { is } \\
\text { merged with age \& cause specific } \\
\text { death rates, population, water } \\
\text { chemistry info, and the share of } \\
\text { water mains }<10 \text { years old. For } 20 \\
\text { of these towns, measured levels of } \\
\text { lead in drinking water are also } \\
\text { known. }\end{array}$ & $\begin{array}{l}\text { Elimination of lead from drinking } \\
\text { water contributed significantly to } \\
\text { falling rates of infant mortality in } \\
\text { the twentieth century. This paper } \\
\text { estimates that the usage of lead } \\
\text { service pipes increased infant } \\
\text { mortality rates by } 25-50 \% \text {, and that } \\
\text { high-acidity water and new lead } \\
\text { pipes contributed to even higher } \\
\text { effects. }\end{array}$ \\
\hline $\begin{array}{l}\text { Zhang (2012) } \\
\text { China } \\
\text { Rollout of treated } \\
\text { water in rural } \\
\text { villages }\end{array}$ & $\begin{array}{l}\text { Individual health indicators (illness } \\
\text { incidence in last month, } \\
\text { weight/height, and height } \\
\text { measures) are regressed on a } \\
\text { village-month level indicator for } \\
\text { water from a water treatment plant, } \\
\text { a moderate set of individual and } \\
\text { household covariates, and region } \\
\text { and year fixed effects. }\end{array}$ & $\begin{array}{l}\text { Health and water source data is } \\
\text { taken from China Health and } \\
\text { Nutrition Survey data from } 7 \\
\text { survey waves on } 4500 \text { rural } \\
\text { households from } 152 \text { villages from } \\
\text { 1989-2006, and is linked to data } \\
\text { (by village) on when water from a } \\
\text { treatment plant was available in the } \\
\text { town. A town is defined as having } \\
\text { plant water when a significant } \\
\text { jump in the share of households } \\
\text { claiming water plant as their } \\
\text { source of water is observed. }\end{array}$ & $\begin{array}{l}\text { Treated water leads to an increase } \\
\text { in the weight to height ratio of } \\
\text { children (avg. age of whom is } 8.9 \\
\text { years) of } 0.446 \mathrm{~kg} / \mathrm{m} \text { and an } \\
\text { increase in height of } 0.962 \mathrm{~cm} \text { on } \\
\text { average. Lower incidence of recent } \\
\text { illness is not detected among } \\
\text { children, although the incidence of } \\
\text { illness among adults is estimated to } \\
\text { decrease by } 11 \% \text { with the } \\
\text { introduction of a water plant. }\end{array}$ \\
\hline
\end{tabular}

